\title{
Inside the Black Box: A Difference-in-Difference Analysis of Shifts in Postsecondary Institution Spending Patterns in Response to "Promise" Financial Aid Programs
}

\author{
Jennifer A. Delaney ${ }^{1}$ and Bradley Hemenway ${ }^{2,3,4}$
}

Using a panel dataset from 2000-2014, this paper employs a difference-in-difference design to consider the impact of the introduction of a "promise program" on postsecondary institutions' internal spending levels and patterns. We find that promise programs influence postsecondary institutional behavior in every area we tested: student-related and non-student-related expenditure levels and shares. We find decreases in student-related expenditure areas at 2-year institutions, but no significant change at 4-years. Non-student-related expenditures are mixed at 2-years with levels of expenditures increasing for auxiliary but decreasing in public service areas. By contrast public service expenditures increase at 4-years. Shares of expenses also shift with declining spending on student services but increased institutional support at 2-years. However, there are no changes to the share of expenses at 4-years. Overall, we find that 2- and 4-year institutions react differently to the introduction of a promise program, with the greatest impact at 2-years.

Keywords: higher education; finance; policy implementation; difference-in-difference; promise programs

JEL Classifications: I22, I23

Version Date: July 17, 2021

\footnotetext{
${ }^{1}$ Associate Professor; Department of Education Policy, Organization and Leadership; University of Illinois at Urbana-Champaign, 217-333-7828, delaneyj@illinois.edu. ORCID 0000-0002-8984-6904.

${ }^{2}$ Data Analyst, Gies College of Business, University of Illinois at Urbana-Champaign, 2302 Fox Drive, Suite D, Champaign, IL 61820, 217-244-4495, hemenwa2@illinois.edu.

${ }^{3}$ We would like to thank William R. Doyle for sharing coding that made creating the event study figures presented in this paper easier. This work has benefited from feedback at the 2016 Illinois Education Research Council conference, the 2016 Association for the Study of Higher Education conference, the University of Illinois Office for Planning and Budgeting in-service (October 2016), and the University of Illinois at Urbana-Champaign Higher Education Collaborative (December 2016).

${ }^{4}$ This research was supported by a grant from the American Educational Research Association which receives funds for its "AERA Grants Program" from the National Science Foundation under NSF Grant \#DRL-0941014. Opinions reflect those of the author(s) and do not necessarily reflect those of the granting agencies.
} 
This paper considers the impact of community-based "promise programs" on internal expenditure decisions in postsecondary institutions. Currently Civic Nation tracks more than 300 promise programs serving communities across 44 US states $(2019) .{ }^{5}$ Student eligibility for promise programs is neither need- nor merit-based, but rather the process of allocation rests on a student's geographic residency. Within a program's geographic area all students are universally eligible for the promise program, potentially increasing higher education access, affordability, and equity. With promise awards granted as early as kindergarten, the these programs provide early information about postsecondary opportunities and affordability that can serve as a catalyst for altering postsecondary attainment goals, changing enrollment patterns, and other student behavioral responses (Andrews, DesJardins, \& Ranchhod, 2010; Bartik \& Lachowska, 2014; Hershbein, 2013; Pluhta \& Penny, 2013). Reflecting their broad impact, promise programs have caught national attention in the "free" college movement (College Promise Campaign, n.d.).

Promise programs also represent a new, reliable revenue stream for postsecondary institutions, since the "promises" made to students translate directly into revenue-based "promises" made to (or by) institutions. The availability of promise tuition dollars, coupled with elevated student enrollment rates, produce a unique environment through which to observe how institutions shift internal finance allocations and levels of expenditures in response to a new revenue stream. The introduction of a promise program has been shown to influence institutional behavior and lead to changes in revenue streams, tuition rates, required fees, institutional aid distribution, and institutional spending decisions (Delaney \& Hemenway, 2020; Gándara,

\footnotetext{
${ }^{5}$ For a comprehensive database of programs categorized as promise programs including these 300 see Perna $\&$ Leigh (n.d.), the Penn AHEAD website, and the database at: https://www.ahead-penn.org/research-projects/collegepromise-programs. For a discussion of which programs should be counted as promise programs see Perna $\&$ Leigh (2018). For a list of comparable promise programs used specifically in this research, their location, and start year see Appendix B.
} 
Billings, \& Li, 2020; Page, Iriti, Lowry, \& Anthony, 2017; Perna, Wright-Kim, \& Leigh, 2020). Building upon this prior research, our work investigates if the introduction of a promise program alters internal expenditure levels and patterns at institutions. We expand prior literature, which predominately considers the impact of one individual promise program, by investigating the effect across multiple promise programs. We also consider if effects are dependent on institutional type, geographic proximity, and expenditure category.

\section{Common Elements of Promise Programs}

Despite growing interest in these programs, there is no common definition of a promise program. In the scholarly literature there is disagreement about which programs should be counted as promise programs (Hemenway, 2018; Perna \& Leigh, 2018). Likewise, there are differences in the number of programs considered promise programs by different organizations. The Upjohn Institute tracks 192 programs, Civic Nation counts over 300 programs, the College Promise Campaign tallies 368 programs, and the Penn AHEAD database contains 425 programs (Civic Nation, 2019; College Promise, n.d., Perna \& Leigh, n.d.; Upjohn Institute, n.d.). Adding to the complexity of the landscape, each promise programs sets their own rules, structures, longevity, and award amounts, and there has been rapid growth of new programs each with unique program rules (for a fuller discussion of program elements please see the typologies developed by Hemenway, 2018; Perna \& Leigh, 2018). However, there are some common features that distinguish promise programs from other forms of student aid or revenue streams for institutions.

Promise program awards are granted to all students from a particular geographic area. All students within the geographic area receive an award regardless of family income or academic achievement. Promise programs offer early information about college affordability since awards 
are granted when students still have time to alter educational aspirations and to change behavior to ensure progression to postsecondary studies. Some promise programs offer guaranteed awards as early as kindergarten (assuming continued residency to maintain eligibility). With their straightforward award criteria (many programs do not require students to complete an application), promise programs provide important information about college affordability. The early nature of promise awards is notable in the context of most other student financial aid awards (federal, state, and institutional), which are often not granted until students' senior year of high school after students have applied to college, been accepted to an institution, complete the Free Application for Federal Student Aid (FASFA), and receive a financial aid award letter. The scope of promise programs ranges from single institution, to multiple institutions, to all institutions in a state. Also, programs may be focused exclusively on community colleges, public 4-years, or, in rare cases, private institutions (Hemenway, 2018; Perna \& Leigh, 2018). In addition, promise programs often bring considerable positive visibility and media attention to institutions.

The funding of promise programs. Just as there are a range of programs, there are a range of funding sources for promise programs. It is a complicated landscape since each promise program has its own unique funding source. We discuss general patterns here because there is no known data source of funding information for promise programs (Perna \& Leigh, 2018).

Broadly, we think of two primary types of funding sources for promise programs - external and internal. Most funding sources offer new money to institutions. "Whether resources come from new dollars (e.g., foundation-funded scholarships) or from reducing resources provided to other initiatives, resources used for a promise program cannot be used for other purposes" (Perna et al., 2020, p. 11). 
One large class of external funders are from the philanthropic community. For example, the El Dorado Promise is funded by the Murphy Oil Corporation and the promise program at Richland Community College in Blue Mound, IL is supported by the Dell and Evelyn Carroll Trust. Promise programs are sometimes launched without warning thereby providing an unexpected revenue stream to institutions as was the case with the sudden start, in 2005, of the Kalamazoo Promise, which is supported by anonymous donors (Andrews et al., 2010).

A second major external funder of promise programs are state and local governments, which also makes our study relevant in the areas of public policy and public finance as we consider the incidence of programs. Arkansas, California, Delaware, Kentucky, Minnesota, Montana, Nevada, New York, Oregon, Rhode Island, and Tennessee offer statewide, statefunded, tuition-free college programs (Powell, 2018). In some cases, state funding is used to incentivize local funding of promise programs. Some states, like California, have offered state incentive funds for localities to create promise programs. Michigan developed "promise zones" to provide tax incentives for additional program creation based on the Kalamazoo Promise model (Miller-Adams, 2015). These "promise zones" create special taxing authority for municipalities to offer bonds to pay for a new promise program. In other places, local communities create promise programs without state incentives. For example, in Hammond Indiana, the College Bound Scholars program provides in excess of $\$ 10,000$ tuition coverage to the children of residents, funded primarily through local government appropriations. The decisions made by institutions in the wake of receiving promise dollars not only affect promise recipients, but also reflect the stewardship of public and philanthropic funds, and there is debate on the efficacy of using public funding for universally accessible promise programs (Dowd, 2008). 
A few promise programs are funded solely by institutional sources. Institutions can create fundraising campaigns to start a new promise program. In addition, it is possible that existing student aid and tuition discounting programs could be repackaged as a promise program. In this case, the institution would leverage all other sources of aid (federal, state, private, etc.), and invest institutional funds to guarantee that any remaining gaps (unmet need) would be covered for each student to create a last-dollar promise program. State and federal student aid, private scholarships, and any earmarked institutional awards (donor-funded) would continue but could be advertised as a promise program with the institutional guarantee of covering unmet need. In addition, it is possible for promise programs to have multiple funding sources. ${ }^{6}$ In all externally funded promise programs and nearly all internally funded programs, promise programs represent new money for institutions. In addition, be the external funding source donors, governments, or institutional boards, these external actors are involved in programmatic decisions related to program design including longevity, eligibility, scope, and value. This creates an outside group that may influence institutional enrollment and internal decision-making.

\section{Research Questions}

We use a panel dataset spanning 2000-2014 with a difference-in-difference (DID) design to explore the impact of promise programs on institutional behavior. Our research questions are based on student- and non-student-related expense categories, both as individual spending components and a share of expenses. We define these categories to be able to consider similar expenditure types and to simplify the language throughout the article. We use the term studentrelated as a general description for whether expenditures are used directly for educating and

\footnotetext{
${ }^{6}$ There are two other possible types of internal funding sources for promise programs, but we know of no examples of these types in operation. We mention them here for completeness. For institutions with large enough endowments, it is possible to redirect endowment funds or change endowment payout rates to pay for an institutionbased promise program. It is possible for institutions to use current operating revenue to support a promise program.
} 
supporting students. Student-related expenditures include instruction, academic support, and student services. Non-student-related expenditures are an overall descriptor of expenses associated with non-teaching aspects of institutions' missions. Non-student-related expenditures include public service, institutional support, auxiliary enterprises, and, at 4-year institutions, research. We also consider the relative distribution of different types of expenditures by presenting findings related to the share of student- and non-student-related expenditure categories. We use share variables that align with each expenditure category. We use both expenditures and shares to reflect both the level of spending in each area and to capture relative shifts in spending following the introduction of promise programs. In this paper we explore two related research questions:

1a. What is the impact of the implementation of a promise program on student- and nonstudent-related current year expenditure categories at postsecondary institutions?

1b. How does the relative share of expenditures differ in student- and non-student-related categories following the introduction of a promise program?

This paper is organized as follows: we begin our discussion with a review of the literature on promise programs broadly. This review considers how these programs change communities, influence student institutional choice, and the ways in which internal expenditure patterns are influenced in postsecondary institutions including institutional responses to promise programs. Next, we detail our conceptual framework drawing on resource dependence theory, which guides our hypotheses. Then, we discuss our dataset and methods, including a description of our identification of promise programs. Next, we describe our empirical results. Finally, we discuss our conclusions, the implications of our findings for various policymakers and stakeholders, and future directions for research.

\section{Literature Review}


This literature review is structured first to consider the existing literature on promise programs, followed by a description of the literature on internal expenditure decisions of postsecondary institutions. We then turn to consider prior literature that shows a relationship between the introduction of a promise program and institutional responses.

\section{Promise Program Literature}

Interest in and academic literature on promise programs continues to expand. The existing literature is primarily centered around promise program's influence on eligible students' behavioral responses: how promise programs change K-12 outcomes, how promise programs influence postsecondary enrollment, and how students' postsecondary performance is shaped by promise programs (for a review please see Swanson, Watson, \& Ritter, 2020). Here, we review the literature on additional outcomes from promise programs: promise programs' role in community changes and promise programs' influence on postsecondary institutional choice. We focus on these bodies of research because, if these areas adjust following the introduction of a promise program, then these programs also hold potential to influence institutional spending decisions.

Promise programs and community changes. A number of studies focus on promise programs as being drivers of economic development in a community. Increased human capital in the local labor force is among the long-term benefits of a promise program. The costs associated with providing postsecondary access for an entire community may be more effective than individual employers bearing labor force training costs and serve a similar purpose as social policy mechanisms (Andrews et al., 2010). After the introduction of a promise program, housing prices are shown to increase by as much as $12 \%$ (LeGower \& Walsh, 2017; Sohn, Rubenstein, Murchie, \& Bifulco, 2017). 
Running Head: Inside the Black Box

Additionally, residents may become more likely to approve upgrades to school facilities. For example, Kalamazoo, MI and El Dorado, AR each passed a local school district construction bond measure following the introduction of their respective promise programs (Miller-Adams, $2010 ; 2011)$. Increased student enrollment in the public schools and elevated property values also add to revenue streams for the local school district (Miller-Adams, 2015). Parents appear to use the availability of promise funds to determine where their children should enroll, especially among minorities, parents with low levels of education, and low-income households (Bartik, Eberts, \& Huang, 2010; Gonzalez, Bozick, Taylor, \& Phillips, 2011). K-12 enrollment gains after the development of a promise program are concentrated on elementary school aged children, who are likely to receive the largest benefit of a graduated award program (LeGower \& Walsh, 2017). Educators and staff perceive a promise program as aligning education goals and creating greater shared accountability within the community (Miron, Jones, \& Kelaher-Young, 2011). For instance, the Kalamazoo Promise indirectly resulted in the development of a tutoring services center in the community and increase parental participation in schools (Miller-Adams, 2011). These prior scholarly pieces present evidence of community-level changes following the introduction of a promise program. This shows the scope and depth of promise programs' influence on communities. Because these changes are visible at the community-level, it seems likely that changes should also be present at the institution-level, which we investigate in our research.

Promise programs and postsecondary institutional choice. Institutions where promise programs are redeemable appear to impact students' postsecondary institution choice, especially type of institution. The introduction of the Knox Achieves program in Tennessee is associated with an $28 \%$ increased likelihood of enrollment, and a $6 \%$ reduction in the likelihood of initial 
enrollment at a 4-year institution, since the Knox Achieves program can only be used at 2-year institutions (Carruthers \& Fox, 2016). Likewise, Gurantz (2020) shows an enrollment shift from 4- to 2-year institutions in the first year following the introduction of the Oregon Promise program. The Pittsburgh Promise appears to have no influence on postsecondary access, but rather altered institutional choice with an increased probability of enrollment at a 4-year institution (Gonzalez et al., 2011). Using standardized test score reporting as a proxy for college choice, Andrews et al. (2010) find that students became more likely to send ACT test scores to a 4-year institution following the announcement of the Kalamazoo Promise program. Additionally, enrollment gains shifted primarily to in-state public 4-year institutions where students would receive the largest Kalamazoo Promise award amounts (Bartik, Hershbein, \& Lachowska, 2021). Prior research has shown that these enrollment effect vary by race and by type of promise program (Bell \& Gándara, 2021; Gándara \& Li, 2020). Likewise, teachers change their expectations (and related behavior) that their students will attend college (Jones, Miron, \& Kelaher-Young, 2012; Ash, Swanson, \& Ritter, 2021). Prior research has shown that promise programs generate student behavioral, enrollment, and college choice changes, which yields changes in enrollment and the composition of student bodies that might cause institutions to alter internal spending behaviors.

\section{Institutional Expenditures}

The literature on postsecondary institutional expenditures is also useful to review when considering possible institutional responses to the introduction of a promise program. This literature shows that newly tapped external revenue sources result in an increase of internal expenditures (Berger \& Kostal, 2002), which follows from Bowen's Revenue Theory of Costs (Bowen, 1977). In addition, prior research shows that changes in external revenue sources can 
influence institutional spending, as institutions tend to align spending to the source of revenue (Leslie, Slaughter, Taylor, \& Zhang, 2012). There is evidence that student financial aid impacts institutions (Long, 2004) and of cross-subsidization in postsecondary institutions (Leslie et al., 2012). Ehrenberg (2002) argues that the mission of an institution is likely to guide the process of allocating finances and cross-subsidization. The reallocation that occurs from cross-subsidization is also likely dependent on the revenue stream and institution type (Ehrenburg, 2002). Leslie et al. (2012) find that $\$ 1$ dollar increase in tuition results in a $\$ 0.46$ increase in instructional costs, $\$ 0.11$ in scholarship funding, and $\$ 0.10$ in student support services. The relationship between tuition share and instructional expenditures is inelastic such that large changes in tuition revenue will create, relatively, smaller changes in educational expenditures (Fowles, 2013). In addition, spending on educational quality and academic prestige is most valued by students at the top end of the student quality distribution (Jacob, McCall, \& Stange, 2018). Our research contributes to literature in this area by testing how institutions change their internal spending patterns in reaction to the introduction of a new revenue stream from a promise program.

Postsecondary institutional responses to promise programs. The literature that specifically examines the influence of promise programs on institutions is small but growing. Delaney and Hemenway (2020) find that the introduction of a promise program alters postsecondary institutional behavior, specifically, behavior related to tuition and fee setting, and grant aid awards. Delaney and Hemenway (2020) also find that the direction of the effects is different for 2- and 4-year institutions, and generally larger magnitudes at geographically proximate institutions. Page et al. (2017) find that institutional behavior related to institutional aid awards is influenced by changes in the Pittsburgh Promise program. Perna et al. (2020) perform a qualitative case study analysis to address gaps in understanding how the structure of 
promise programs alter program outcomes. In focusing on the question if promise programs are an effective use of resources, they show that specific characteristics of the program may influence social goals of both vertical equity and efficiency. They find that because promise programs are universal and awarded to students who would have attended college anyway, the programs are often inefficient. They also find vast differences in both promise program and institutional support for personnel, facilities, and materials to administer programs. The availability of these resources influences the effectiveness of promise programs for both eligible and ineligible students, which raises equity concerns. Gándara et al. (2020) investigate how promise programs influence institutional behavior, and specifically consider how these programs impact revenues at community colleges. Expanding upon this prior literature our work explores if the introduction of a promise scholarship alters internal expenditure decisions at both 2- and 4year institutions.

\section{Conceptual Framework and Hypotheses}

For its conceptual model, this study relies on Pfeffer and Salancik's (1978) resource dependence theory. Specifically we draw upon the idea that institutions are bound to their external environment, which is the context in which institutions make decisions that includes their physical environments, the economic conditions of their state and local governments, political environments, legal constraints, and other organizations upon which they depend. Indeed, prior research has shown that postsecondary institutions react to their environments (for example, Slaughter \& Rhoades, 2009; Slaughter \& Leslie, 1999). Resource dependence theory is commonly used in other research related to postsecondary institutional spending (see for instance, Slaughter \& Rhoades, 2009; Slaughter \& Leslie, 1999; and Leslie et al., 2012). 
Running Head: Inside the Black Box

\section{Avenues by which Promise Programs Have the Potential to Influence Institutional \\ Decisions}

Promise programs have the potential to impact institutions through a number of important avenues including the new revenue that is brought to institutions, program size, how promise programs shift enrollments, and through a signaling effect. We discuss each of these paths below to tie our logic to the conceptual framework. We make the case that promise programs represent a substantial change in the external environment of institutions, which has the ability to change internal decision-making, especially with regard to institutional expenditures.

Promise programs as new institutional revenue. As discussed in the introduction, there are multiple paths by which promise programs are funded. Promise programs that are funded by donors outside an institution - philanthropic, state and/or local government funding - represent new money directed at postsecondary education. In most cases institution-based funding sources - institutional fundraising and/or repackaging existing merit- or need-based grant aid programs also result in new money for an institution. As a new revenue stream, we expect promise programs to have the ability to influence institutional decision-making. This is supported by prior literature since Gándara et al. (2020) find that programs that operate at a single 2-year institution are associated with significant increases in revenue.

Promise program size. Promise programs are generally large enough to elicit institutional responses. The unique method of most promise programs to grant awards without any application process results in larger geographically-based, universally-eligible pools of students than most scholarship programs. For example, approximately $70 \%$ of Kalamazoo Promise students enroll in two local institutions, Kalamazoo Valley Community College (KVCC) and Western Michigan University (WMU) (W. E. Upjohn Institute for Employment 
Research, 2016). At KVCC, 2,048 Kalamazoo Promise students enrolled between 2006-2014 generating over \$4 million in first-dollar funding to the institution (Mack, 2014). Similarly, Richland Community College's annual incoming class is about 9\% Dell and Evelyn Carroll Scholarship students (approximately 90 students) from Blue Mound, IL (Hemenway, 2018). In the first year of the El Dorado Promise, 29\% of El Dorado Promise students attended South Arkansas Community College (SACC) accounting for a 16\% bump in enrollment (El Dorado Promise, 2015). With substantial portions of each student body participating in promise programs, the size of these programs is large enough to impact institutional behavior.

\section{Promise program impact on enrollment and associated student-based revenues.}

With any funding source that generates new money for institutions, an increase in total enrollment would not be necessary for the institution to receive these new revenues. Depending on the promise program rules, both already enrolled students and new students who would have attended anyway would bring new money in the form of promise dollars thereby increasing revenue for institutions. However, past research has also shown that promise programs alter enrollment patterns and increase the number of students attending institutions with promise programs (Swanson et al., 2020). In fact, there is evidence that promise programs increase total enrollment through two populations: both eligible (Andrews et al., 2010; Bartik et al., 2021; Hershbein, 2013; Hemenway, 2018; Page et al., 2017; Swanson et al., 2020) and ineligible (Perna et al., 2020) students. This results in increased student-related revenue for institutions such as tuition and fees. In addition, there is evidence that promise programs increase persistence among enrolled students thereby retaining students (and their promise dollars) longer at each institution and reducing enrollment churn (Carruthers \& Fox, 2016). Therefore, promise 
programs generate new revenue for institutions both through expenditures on existing students and enrollment shifts that bring in (and retain) new students who also carry promise funds.

Promise programs as signaling. Perna et al. (2020) find both that promise programs increase enrollments among students who are not eligible for the program and that promise programs improve outcomes among ineligible students. These outcomes for ineligible students represent a signaling effect - such that the existence of the program impacts students who do not receive promise dollars. For low-income students, last-dollar programs can mean that students who are eligible for promise programs do not actually receive an money from the promise program because other forms of students aid - state aid and federal grants (like the Pell grant) already cover their tuition. In fact, prior research has shown increased postsecondary attendance in last-dollar programs among students who are eligible for other forms of financial aid and do not receive money directly from a promise program (Carruthers \& Fox, 2016; Gonzalez et al., 2011; Pluhta \& Penny, 2013). Among these eligible students, the promise program primarily has signaling and informational effects since no funds are received from the program. The informational effects provide early information about college (sometimes as early as kindergarten) when students are still able to make a college-going decision and prepare for postsecondary enrollment. There is also a strong signaling effect for institutions, which can help to shift enrollments and bring positive attention to campuses. Hemenway (2018) argues that promise programs are a unique form of advertising postsecondary affordability. Because prior research has found evidence of a signaling effect for non-eligible students, our work considers all pathways by which promise programs may impact behavior including both signaling and financial awards. 
A small prior literature has shown that promise programs influence institutional spending (Delaney \& Hemenway, 2020; Gándara et al., 2020; Page et al., 2017; Perna et al., 2020). In addition, because program funders shape the eligibility rules, scope, generosity, and longevity of promise programs, these programmatic features of promise programs also have the ability to influence institutional decisions. In addition, institutions tend to allocate resources dependent on the revenue source. For instance, past research has shown that the largest share of tuition revenue is allocated to student-related spending (Leslie et al., 2012; Fowles, 2013). Because of this, we test the impact of promise programs by considering the alignment between this new revenue source and select institutional expenditure categories. In particular, we posit that the introduction of a new student-based revenue source, promise scholarship dollars, will lead institutions to increase spending in student-related areas.

\section{Hypotheses}

Our hypothesis is shown in Figure 1. The lines represent the student-related expenditure category of instructional expenditures over time. When a promise program is introduced, the treatment group (institutions that enroll students with promise scholarships) is expected to experience an increase in instructional expenditures in excess of any secular trend such that Instruction $_{2}>$ Instruction $_{1}$. The hypothesized difference in the increased levels of expenditures on instruction after the enactment of a promise program are the treatment effect. Figure 1 illustrates only the hypothesis for instructional spending, but we anticipate similar types of effects for all other areas of student-related spending.

In this work we also test non-student-related spending categories. Because there is not alignment between the source (a student-based revenue stream) and non-student-related spending 
areas, we do not expect to find a significant effect of the introduction of a promise program on institutional spending in these areas.

The tight coupling of promise programs and their communities likely yields increased informal oversight of institutional spending. However, institutions differ in their connectedness to local communities and we expect that local control is likely differentiated by institutional type. True to their names, community colleges historically developed to be of their communities and to serve local areas (Chen, 2021). Most students do not leave home to attend community colleges and few 2-year institutions offer on-campus living options. Most community college graduates remain in their communities after graduation with $61 \%$ staying within 50 miles of the college compared to $40 \%$ of 4 -year graduates staying within 50 miles of their university (Sentz, Metsker, Linares, \& Clemans, n.d.). Often there is overlap or connections between local community college governing boards and the local leaders, politicians, and philanthropies that start promise programs. The local context of community colleges implies that their networks work in smaller geographic areas than in larger statewide programs, especially those that involve multiple institutions. These connections within the community likely yield additional informal oversight of promise programs at community colleges. Therefore, we hypothesize that community colleges will react more strongly regarding student-based educational expenses, as compared to 4-year institutions. We address this hypothesis by examining the relative share of student- and nonstudent-related spending by institutional type. Considering spending shares allows us to capture not only changes in spending levels, but also changes in the relative size of spending in these areas.

\section{Data}


We constructed a dataset for this study using data primarily from the DCP dataset. The DCP dataset combines multiple years and surveys of the Integrated Postsecondary Education Data System (IPEDS) into a single longitudinal database. Using the DCP dataset is the best option for our research since this dataset offers consistent measures of variables for postsecondary institutions, especially in expenditure categories. In particular, we appreciated the work that the DCP team put into creating share measures that are useful for our analyses and therefore found the DCP dataset to be a preferable source as compared to IPEDS. However, there are some limitations of using the DCP. In particular, Jacquette and Parra (2016) describe potential issues with how parent/child campuses are defined since the DCP treatment differs from IPEDS. However, this is not an issue in our study since we use only a single data source (DCP) that is comparable across years. This helps to avoid introducing biases or definitional issues with parent/child campuses that could come from combining multiple datasets. In addition, our method measures the differences from one time period to the next. As such, the measured change in value is compared to the change in value within institutions using a single consistent dataset.

Our dataset ranges from fall academic years 2000-2014 and is identified at the institutionyear level. ${ }^{7}$ For variables that are measured by calendar year, we align the measures to fall academic year by subtracting one year. For example, a variable measured in calendar year 2015

\footnotetext{
${ }^{7}$ We only include institutions located in one of the US states for our sample (all institutions from the District of Columbia and US territories are excluded). No for-profit institutions are included in our study. We are not aware of any for-profit institutions that have promise programs, which is consistent with the very low levels of institutional aid offered at these institutions. We additionally chose to exclude non-profit private institutions since most students use promise awards at publics. We also anticipate that private institutions will behave differently from publics, and financial data on private institution spending both uses different accounting standards and is less transparent. Only institutions categorized as "Public" (control), "Public, 4-year or above" or "Public, 2-year" (sector), that offer "Four or more years" or "At least 2 but less than 4 years" (iclevel), that have one of the following Carnegie classifications "Public Research", "Public Master's", "Public Associate's", "Public Bachelor's" (carnegie_sector_2010), and are not a "US Service school" (oberegion) are included in the dataset.
} 
would align to fall academic year 2014, referring to the fall semester of academic year 20142015. We adjust all financial data for inflation to fall academic year 2014 using the consumer price index (CPI). Dollar values and all enrollment measures are logged to address the skewedness of the distributions of these variables. We coded promise program characteristics based on Hemenway's (2018) typology, as described in more detail in the section below.

The dependent variables of interest in our study are student-related expenditures, and non-student-related expenditures. As discussed in the introduction, the student-related expenditures category is a broad category encompassing expenses related directly to instruction and includes instruction, academic support, and student services. Instruction contains only the expenses associated with the act of instruction. Academic support captures any activity and services aligned with instruction, research, or public service - such as media, library, personnel development, and curriculum development expenses. Student services expenses include expenses for admission or registrar activities as well as expenses aligned with student well-being (physical or emotional) and student intellectual, cultural, and social development outside of formal instruction.

We use the term non-student-related expenditures to capture institutional expenditures in other areas including public service, institutional support, and auxiliary enterprises. Public service expenses capture any non-instructional services designed to benefit groups external to the institution. Examples of public service expenditures are: holding conferences, staffing reference bureaus, cooperative extension programs, and public broadcasting services. Institutional support is day-to-day operational support and general administrative/executive activities including legal services, employee personnel records management, purchasing, and public relations. Auxiliary enterprises are self-supporting operations designed to provide a service to students, faculty, or 
Running Head: Inside the Black Box

staff, such as residence halls, food services, student health services, college stores, and parking. All variables that we use in this research exclude any expense that has a separate line item, such as all administrative (Academic Deans or support staff) expenses. Additional expenditure categories such as building and maintenance are not included in our models. The official DCP definitions for all covariates, including the DCP-constructed share variables, can be found in Appendix C.

\section{Identification of Promise Programs}

One contribution of this work is that it tests the effects of multiple promise programs simultaneously, and includes different types of promise programs. We use Hemenway (2018) to identify comparable sub-state level promise programs at public institutions for inclusion in this work. Using cluster analysis, Hemenway (2018) reviews 199 scholarship programs and identifies three types of residency-based programs: state-based, institutional no loan, and community sustained. In this work we draw from the community sustained group, which is comparable to the programs used in the typology created by Perna and Leigh (2018). We further disaggregate our sample of public institutions to consider different effects for 2- and 4-year institutions. Data on promise programs was collected from a variety of public sources and is coded at the institution-year level (Hemenway, 2018). Start years for programs are coded as the implementation year (the first year when students could enroll in an institution using promise funds) not the year in which the program was first announced. Appendix B provides a list of institutions in the dataset that receive students with promise scholarships, the state where the institutions are based, the first year when an institution could receive promise funds, a representative name of a promise program from which funds are received, and the type of promise program. 
Running Head: Inside the Black Box

\section{Methodology}

Selection bias and omitted variable bias present a challenge in higher education research and require mindful consideration in research projects (Cellini, 2008). This study seeks to address these issues by using a DID design. After enrolling students who carry promise scholarship funding, the treatment groups (i.e., public institutions that receive students with promise scholarships) are expected to reallocate resources toward student-related expenditures, as compared to the control group (i.e., public institutions that do not enroll students with promise scholarships). DID designs are agnostic to how policy changes are actualized, but rather identification rests on the change (policy introduction) itself. DID designs can be used to investigate the impact of rule or regulation changes that may be entirely decoupled from funding. As such, it does not matter within DID designs if promise programs change institutional behavior due to new money being received or a signaling effect. In either instance, the DID framework is appropriate since it investigates the impact of a policy change. There is a rich literature that uses DID designs to consider the impact of scholarships or other grant-aid programs (see for instance, Cohodes \& Goodman, 2014; Singell, Waddell, \& Curs, 2006; Sjoquist \& Winters, 2012). Our work on promise programs aligns nicely with these prior scholarly works testing the impact of the introduction of a new scholarship program.

\section{Model Specifications}

The variable of interest in our models is an interaction between an indicator variable for those institutions that receive promise funds and an indicator variable for the years after the enactment of the program. The dataset is a cross-sectional time series and identified by institution, $i$, and year, $t$. The variable of interest seeks to capture institutions in years in which students enrolled with promise funds. Promise $_{i t}$ equals 1 if institution, $i$, has a promise program 
in place in year, $t$. Promise $_{i t}$ equals 0 if institution, $i$, does not have a promise program in place in year, $t$. Often this term is shown as an interaction term in estimating equations (such as Promise $_{i}{ }^{*}$ Post $_{t}$ ), but we use a simpler and mathematically equivalent form for parsimony. We include a vector of time-varying common covariates, $\mathbf{X}_{i t}$ (as discussed below), institution fixed effects (represented by $\mu_{i}$ ), year effects (represented by $v_{t}$ ), and the error term $\varepsilon_{i t}$. Below we show Equation 1 for current year expenditures for instruction total (logged and CPI adjusted), but the same model is also applied to the other outcome variables tested in this work:

$$
\text { LogInstruction }_{i t}=\beta_{1} \text { Promise }_{i t}+\mathbf{X}_{i t} \boldsymbol{\gamma}+\mu_{i}+v_{t}+\varepsilon_{i t}
$$

\section{Parallel Trend Assumption}

One underlying assumption in DID models is that treatment and control groups are on a similar trajectory prior to the policy intervention. As such, a first step in this analysis is to determine that the outcome measures tested at institutions that receive promise funds are on a similar trend line to other institutions. We follow the approach described in Angrist and Pischke (2009) by plotting coefficients (and confidence intervals) of a series of regressions with indicator variables for each of the four prior years and each of the four years following the implementation of a promise program. ${ }^{8}$ The unique start year for each program is accounted for by labeling the years in one-year incremental pre- and post-promise time periods. We show graphics for current year expenditures for instruction (logged and CPI adjusted) for single 2-year, nearest neighbor 2year, and nearest neighbor 4-year institutions in Figure 2. All images included in Figure 2 have confidence intervals that cross zero for all years showing support for having met the parallel prior year trends assumption in DID designs.

\footnotetext{
${ }^{8}$ To ensure consistency between the models tested, these regressions used the same control variables as described in the discussion of control variables below.
} 


\section{State-Specific Linear Time Trends}

While Figure 2 shows evidence that all of the models tested in the main part of the paper meet the assumptions of parallel prior year trends in DID models, some of the event time figures for the models discussed in the appendix show the potential for non-parallel prior years. Out of an abundance of caution and because there is no definitive test to identify prior year trends, we chose to employ an additional modeling technique in both the main text and the appendix. This will ensure both consistency and comparability across all of the models presented in this work. We control for state-specific linear time trends because institutions are nested within states and do not change states over time. Including unit-specific linear (or quadratic) time trends can influence estimates obtained from DID models (for a discussion see, Friedberg, 1998; Jacobson, LaLonde, \& Sullivan, 1993). In this work, we run models with state-specific linear time trends based on the assumption that there are no other factors (beyond common covariates) that would change the supply or demand for higher education in promise institutions, relative to other institutions during this time period. Using the rationale described by Wooldridge (2002) we present the state-specific linear trend as a growth rate at institution, $i$, with the term, $g_{i} t$. Below, we show the estimating equation (Equation 2) for current year expenditures for instruction total (logged and CPI adjusted). Despite concerns about an over-specified model, all of the results presented in this paper incorporate state-specific linear time trends using models similar to the estimating equation (Equation 2). ${ }^{9}$

$$
\text { LogInstruction }_{i t}=\beta_{1} \text { Promise }_{i t}+\mathbf{X}_{i t} \boldsymbol{\gamma}+g_{i} t+\mu_{i}+v_{t}+\varepsilon_{i t}
$$

\footnotetext{
${ }^{9}$ We acknowledge the concerns over time-varying effects in two-way fixed effects DID models (Goodman-Bacon, 2018), but to-date there is no consensus in the field about the best approach for addressing this. Prior literature has shown that including state-specific linear time trends can matter to estimates produced in DID models, which we have implemented in all of the models presented in this paper to help address these concerns.
} 
Running Head: Inside the Black Box

\section{Treatment and Control Groups}

A critical aspect of DID designs is a clearly defined control group. For our research, the various program designs used by promise programs make the endeavor of identifying comparable control groups challenging. For example, the Great River Promise in Blytheville, AR offers scholarships for students from Mississippi County Public Schools only to attend Arkansas Northeastern College. In this instance, the treatment is limited to a single institution, so the identification of treatment and control groups is clear. Approximately half of the promise programs identified in this work can only be used at one single institution. However, there are other programs, like the Kalamazoo Promise, that allow enrollment at a number of different institutions and institution types. The Kalamazoo Promise awards scholarships to students from Kalamazoo Public Schools to attend any public or private postsecondary institution in the state of Michigan, either 2- or 4-year. In this instance, multiple institutions may receive students with Kalamazoo Promise awards, so the treatment and control groups are not as clearly defined. In addition, we expect different magnitudes of effects based on the geographic distance between the promise program and each institution. Identifying the treatment and control groups for a program that can be used at multiple institutions is more challenging and requires us to use multiple tactics.

We take two approaches. First, we run analyses that restrict our sample to programs that can be used only at one institution (Single2yr or Single4yr). This is the most straightforward analysis since the treatment and control groups are easily discernible. There are 192-year institutions and two 4-year institutions for which we can use this single institution coding, as listed in Appendix B. 
Second, we posit that the institution geographically nearest to the location of a promise program will be most strongly influenced by the introduction of a scholarship program. To test this, we create a treatment group of the geographically nearest neighbor institutions, which are eligible to receive students with promise funds. ${ }^{10}$ Our comparison group is all other institutions that are not geographically proximate, by institutional types. For example, the nearest 2-year institution for the El Dorado Promise program is South Arkansas Community College, and the nearest 4-year institution is Southern Arkansas University. Our estimating sample contains 18 nearest neighbor 4-year institutions (Nearest4yr) and 36 nearest neighbor 2-year institutions (Nearest2yr), as shown in Appendix B. This approach allows us to identify the postsecondary institutions that are most likely to receive promise funds. Consequently, the nearest neighbor institution measure likely represents the highest dosage effect of these programs on institutional behavior. We use the College Simply (2015) database and mapping features in MapQuest (2015) to identify the nearest neighbor institutions for each promise program. ${ }^{11}$

Using multiple definitions and categorizations of institutions that receive promise funds enables us to attend to specific program rules while attempting to minimize "contamination" within each control group. The multiple tests also allow us to trade off concerns about "contamination" in the control group with sample size. We understand that by accurately

\footnotetext{
${ }^{10}$ The term "nearest neighbor" is not meant to imply the use of Propensity Score Matching. We use this terminology as a description of the proximity between the graduating high school for the promise program and the closest eligible postsecondary institution by institutional type.

${ }^{11}$ With the nearest neighbor coding there is the possibility of some "contamination" in the control group because some institutions that receive promise funds from statewide programs will be included in the control group. Despite differences in the enrollment proximity among gender, first generation student status, parental education and income, academic performance, state of residence, and race/ethnicity, Mattern and Wyatt (2009) show that 26\% of college students in the U.S. attend college within 25 miles of their home and $71 \%$ of college students travel less than 200 miles from home for college, on average. As such, the postsecondary institutions geographically located closest to the site of a promise program (and often located within the school district boundaries of the awarding program) are the most likely to be influenced by a promise program.
} 
modeling promise program rules while attending to the requirements of a DID design complexity is added to this work, but we think it is important to be able consider the effects of multiple promise programs in a single study. Appendix A contains additional models that strictly follow the program rules of the promise programs, but are less well-suited to meet DID model assumptions.

\section{Common Covariates}

Common covariates, represented by the vector $\mathbf{X}_{i t}$, in Equation 2 are used in all of the models tested to increase the precision of the estimates reported. Because there is the potential for institutions to achieve size-related economies of scale, institutional size might matter for internal expenditures. As such we control for the logged total number of students enrolled at each institution with a one-year lag. We also control for a major revenue stream at public institutions - state and local appropriations. We use a measure of state and local appropriations (logged with a one-year lag and CPI adjustment) to account for differences in local spending for higher education by state, especially at 2-year institutions. Finally, in order to capture the total fiscal size of an institution, we control for total current funds revenues (logged with a one-year lag and CPI adjustment). Table 1 presents descriptive statistics of the variables used in the analyses.

\section{Results}

The results section is organized to first consider the results for student- and non-studentrelated expenditure categories. Following these discussions of funding levels, we consider the relative share of funding in student- and non-student-related categories. Our results are organized to consider three different types of promise programs that designate: (1) a single 2-year institution for awards (Single2yr), (2) the nearest neighbor 2-year institution of a promise 
program (Nearest2yr), and (3) the nearest neighbor 4-year institution of a promise program

(Nearest4yr). Due to small sample size, we do not show results for single 4-year institutions.

\section{Current Year Expenditures}

We begin by considering current year student-related expenditures on instruction, academic support, and student services. These are all expenditure categories that directly impact student experiences including both in-class experiences (via instruction and academic support) and out-of-class support (via student services). They are also expenditure categories that are likely enrollment-driven and should therefore respond to changes in enrollment levels following the introduction of a promise program.

2-year institutions. Table 2 shows the results for 2-year institutions and, in general, we find decreases in student-related expenditures. We find negative results for both of the instruction models, but only significant results for nearest neighbor institutions $(\mathrm{p}<0.05)$, with a $3.3 \%\left(100\left(\mathrm{e}^{0.0327}-1\right)\right)$ decline in instruction spending following the introduction of a promise program, all else equal. ${ }^{12}$ The effect of promise programs on institutional spending on student services is significant and negative for both measures of promise programs $(\mathrm{p}<0.01)$. Following the introduction of a promise program, the magnitude of the decreases in student services spending are 15.4 and 9.3\%, respectively (by promise program type), as compared to 2-year institutions that do not receive students with promise funds, all else equal. These results do not show alignment between the introduction of promise funds at an institution and increased investment in student-related expenditures. In fact, 2-year institutions appear to decrease

\footnotetext{
${ }^{12}$ We follow the approach discussed by Giles (2011) for interpreting coefficients when using dummies in log linear models. Throughout the results section, our magnitude interpretations are in relation to the dummy variable moving from 0 to 1 . Using the notation from equation 2, we calculate the percent impact of the dummy (Promise $e_{i t}$ ) on $Y$ $($ Instruction TotalLog $i t)$ as $100\left[\mathrm{e}^{\beta 1}-1\right]$. For the sake of brevity, we only show the calculation in the text the first time it is presented.
} 
expenditures in these areas when promise dollars are introduced, as compared to 2-year institutions that do not receive students with promise funds. This is the opposite direction of our hypothesis and of similar effects found in prior research (see for instance, Leslie, et al., 2012).

Turning to non-student-related expenditures, we consider three types of expenditures categories: public service, institutional support, and auxiliary enterprises. These categories capture expenditures that may be important to institutional missions (like public service), but are not directly related to undergraduate instruction and are likely not enrollment-driven. At 2-year institutions (Table 2), we find large, negative, significant effect on public service expenditures at single and nearest neighbor promise programs ( $\mathrm{p}<0.05$ or smaller). The magnitude of the decreases ranges from $39 \%$ at promise programs that can only be used at a single institution to $59 \%$ at nearest neighbor institutions. We find no significant effect on institutional support. We find a positive effect in all of the models of auxiliary expenditures, and borderline significant effects in nearest neighbor model. These expenditures increase by $19.2 \%$ for 2 -yr institutions with promise funding. This finding indicates that institutions increased spending on auxiliary enterprises, like food services and athletics, following the introduction of a promise program as compared to institutions that did not receive students with promise funds, all else equal.

4-year institutions. When considering the influence of promise programs on 4-year institutions' student-related expenditures (Table 3), we find no significant effects, which stands in contrast to the behavior of 2-year institutions. Taken together, these results show that 2- and 4year institutions behave differently with regard to student-related expenditures following the enrollment of students with promise dollars, as compared to institutions that do not enroll promise students, all else equal. 
Running Head: Inside the Black Box

Turning to consider non-student related expenditures (Table 3), at 4-year institutions, we find a positive, significant effect of $14.5 \%$ on public service at nearest neighbor institutions $(\mathrm{p}<0.1)$. For both 2- and 4-year institutions we find evidence that the introduction of promise programs impacts non-student-related spending levels across multiple areas of spending.

\section{Share of Expenditures}

We next turn to consider the relative share of institutional expenses in both student- and non-student-related categories. The share measures indicate if there was a change in the relative standing of an expenditure area as opposed to simply an increase (or decrease) in levels of spending. This allows us to capture relative importance of different expenditure categories that could be masked by overall increases (or decreases) in institutional spending. For both 2- and 4year institutions, we consider the following student-related share categories: instruction and student services. For both institution types, we also consider the following non-student-related share categories: academic and institutional support and operations and maintenance share, and public service. For 4-year institutions, we additionally consider the non-student-related share category of research.

2-year institutions. Table 4 presents the results of models that consider student-related share of expenses at 2-year institutions. We do not find a significant effect of the introduction of a promise program on the share of education and related expenses spent on instruction. When considering the share spent on student services, we find a negative effect across both the single institution and nearest neighbor models ( $\mathrm{p}<0.1$ or smaller). The significant declines in share spent on student services ranges from $0.8-1.6 \%$.

When considering the non-student-related shares of expenses for 2-year institutions (Table 4), we find positive results for both types of promise programs in the share of education 
and related expenses spent on academic and institutional support and operations and maintenance. The models for single institution and nearest neighbor programs are significant at traditional levels ( $\mathrm{p}<0.05$ or smaller), ranging from a $1.3-2.15 \%$ increase in share of spending in this non-student-related category. We do not find a significant effect on the share of spending in the public service category. When taken together with the findings from the student-related share analyses, it appears that student-based promise funds are not being used for instruction or student services, but are instead being used to shift a larger share of the institution's budget to providing central administration support, maintenance, and similar types of expenses at 2-year institutions.

4-year institutions. Table 5 presents results for student-related share of expenses at 4year institutions. We do not find a significant effect of introducing a promise program on the share of education and related expenses spent on either instruction or student services. Likewise, we find no significant effect of spending for any of the three non-student-related categories for 4year institutions. Promise programs appear not to change the relative share of spending across student- and non-student-related categories at 4-year institutions. As with the findings related to levels of spending, these results suggest that 2- and 4-year institutions react differently to the introduction of a promise program with 2-year institutions being more reactive to the programs as reflected in the changes in their internal spending behavior.

\section{Conclusion Policy Implications, and Future Directions for Research}

This work makes a contribution to the literature by exploring the effects of promise programs on the behavior of postsecondary institutions with regard to their internal spending patterns. We find that promise programs influence postsecondary institutional behavior in every area we tested: student-related and non-student-related expenditures, and student-related and non-student-related shares of expenditures. The patterns of expenditures that we document in this 
work do not neatly align student-based resources (promise scholarship funds) with studentfocused expenditures as we had hypothesized.

We also find evidence that the effects of promise programs are different for 2- and 4-year institutions. As is often the case in higher education research, these findings underscore the importance of disaggregating samples to explicitly consider institutional type. In addition, the differences in findings by institutional type likely indicate that local control is important, as community-based scholarship programs may exert different levels of informal oversight at community colleges as compared 4-year institutions. Our results suggest that the stronger local ties (and informal oversight) at community colleges appear to have an impact on how promise programs influence internal institutional expenditures. Broadly, the unique treatment of the introduction of a community-based scholarship program offers insights into how institutions do (and do not) shift internal finance allocations and levels of expenditures in response to changes in student-based revenue streams.

The findings from this study also provide valuable information about effectiveness and unintended consequences for promise program funders including both the philanthropies and governments that support these programs. If funders expect to have their scholarships be used to support student-related activities at postsecondary institutions, then the findings of this study are likely troubling since we did not find clear alignment between the introduction of a studentrelated promise program and student-related institutional expenditures. This concern aligns with conclusions drawn in prior research about how promise funds are viewed and used by institutions (Delaney \& Hemenway, 2020; Gándara et al., 2020; Page et al., 2017; Perna et al., 2020). If the intent of the promise program is to help improve vertical equity and increase educational advancement (Perna et al., 2020), we would hope to find that promise-eligible institutions 
increase spending in areas associated with student support. Perna et al. (2020) describe the importance of this alignment and note that promise programs often create access for students who will require additional institutional support to be successful. Absent institutional spending on student-related expenses, promise students may have a reduced likelihood of successfully earning postsecondary credentials. In addition, if promise programs change the allocation of resources between eligible and ineligible students, promise programs may decrease postsecondary outcomes (persistence and degree completion) of ineligible students, making ineligible students worse off than before the introduction of a program (Perna et al., 2020). Using fine-grained qualitative research, Perna et al. (2020) suggest that "programs may influence student outcomes by altering resource allocations and other aspects of the destination community college. For example, when no new staff are hired, program personnel may reduce time spent on other institutional functions. This shift may reduce resources and outcomes for those who are ineligible for the program. On the other hand, implementing a program may lead to changes that improve outcomes for all enrolled students" (p. 12). Stakeholders, and promise program funders in particular, should take our findings into account when updating existing programs or developing new programs, and consider how promise programs influence institutional expenditures and support for all students.

In the future, we hope researchers will continue to explore the effects of promise programs, as they offer unique insights into student and institutional behavior, especially given current political interest in the "free" college movement. In particular, we think there is a need for exploration of the long-term effects of promise programs on students and the effect of promise programs on private institutions. In addition, more research is needed about how institutions make internal expenditure decisions, the alignment between revenues and 
Running Head: Inside the Black Box

expenditures, and the impact of promise programs on educational quality. We also hope that more work will be done using both quantitative and qualitative methodologies to categorize and analyze community-level student financial aid programs. New promise programs continue to be developed across the US and future analyses should also explore these newer programs. 


\section{References}

Andrews, R., DesJardins, S., \& Ranchhod, V. (2010). The effects of the Kalamazoo Promise on college choice. Economics of Education Review, 29, 722-737.

Angrist, J. D. \& Pischke, J-S. (2009). Mostly harmless econometrics: An empiricist's companion. Princeton University Press: Princeton, NJ.

Ash, J., Swanson, E., \& Ritter, G. (2021). A promise kept? The impact of the El Dorado Promise Scholarship on student achievement. Educational Evaluation and Policy Analysis, 43(1), 83-107. https://doi.org/10.3102/0162373720970512

Bartik, T. J., Eberts, R, \& Huang, W. (2010). "The Kalamazoo Promise, and enrollment and achievement trends in Kalamazoo Public Schools." Presented at the PromiseNet 2010 Conference, June 16-18, Kalamazoo, MI. http://research.upjohn.org/confpapers/15Accessed 7/24/2016. Accessed 7/24/2016.

Bartik, T. J. and Lachowska, M. (2014). The short-term effects of the Kalamazoo Promise Scholarship on student outcomes. In New Analyses of Worker Well-Being (Research in Labor Economics, Vol. 38), Emerald Group Publishing Limited, Bingley, 37-76. https://doi.org/10.1108/S0147-9121(2013)0000038002

Bartik, T., Hershbein, B., \& Lachowska, M. (2021). The effects of the Kalamazoo Promise Scholarship on college enrollment and completion. Journal of Human Resources, 56(1), 269-310

Bell, E., \& Gándara, D. (2021). Can Free Community College Close Racial Disparities in Postsecondary Attainment? How Tulsa Achieves Affects Racially Minoritized Student Outcomes. American Educational Research Journal. https://doi.org/10.3102/00028312211003501

Berger, M. C., \& Kostal, T. (2002). Financial resources, regulation, and enrollment in US public higher education. Economics of Education Review, 21(2), pp. 101-110.

Bowen, H. R. (1977). Investment in learning: The individual and social value of American higher education. Jossey-Bass: San Francisco.

Carruthers, C. K. \& Fox, W. F. (2016). Aid for all: College coaching, financial aid, and postsecondary persistence in Tennessee. Economics of Education Review, 51(C), 97-112.

Cellini, S. (2008). Causal inference and omitted variable bias in financial aid research: Assessing solutions. Review of Higher Education, 31(3), 329-354.

Chen, G. (2021). What is a community college? Community College Review. https://www.communitycollegereview.com/blog/what-is-a-community-college

Civic Nation (March 1, 2019). There are 300+ college promise programs in 44 state and more to come in 2019. https://civicnation.org/news/there-are-300-college-promise-programs-in44-states-and-more-to-come-in-2019/

Cohodes, S. R., \& Goodman, J. S. (2014). Merit Aid, College Quality, and College Completion: Massachusetts' Adams Scholarship as an In-Kind Subsidy. American Economic Journal: Applied Economics, 6 (4): 251-85. DOI: 10.1257/app.6.4.251

College Promise Campaign (n.d.) [website] Retrieved from https://collegepromise.org/ Accessed $3 / 31 / 2020$.

College Simply. (2015). Nearest colleges by state [Data file]. Available from: http://www.collegesimply.com/colleges-near/

Delaney, J. A., \& Hemenway, B. (2020). A difference-in-difference analysis of "promise" financial aid programs on postsecondary institutions. Journal of Education Finance 
45(4), 459-492. https://www.muse.jhu.edu/article/760724. Delta Cost Project (n.d.) [Data file]. Multiple years. Retrieved from http://www.deltacostproject.org/index.asp

Dowd, A. C. (2008). A cautionary analysis of restrictive "promise" tuition guarantees: The case of the Kalamazoo Promise. Houston, TX: University of Houston Law Center.

El Dorado Promise. (2015). El Dorado celebrates second anniversary of promise scholarship program. Retrieved from http:/www.eldoradopromise.com/new/storyID $=4$

Ehrenburg, R. (2002). Tuition rising. Harvard University Press.

Fowles, J. (2013). Funding and focus: Resource dependence in public higher education. Research in Higher Education, 55(3), pp. 272-287.

Friedberg, L. (1998). Did unilateral divorce raise divorce rates? Evidence from panel data. American Economic Review, 88(3), 608-627.

Gándara, D., Billings, M., \& Li, A. (2020). Stretched thin? Promise program effects on community colleges' revenues. Conference paper presented at the Association for Education Finance and Policy, Fort Worth, TX (virtual conference).

Gándara, D., \& Li, A. (2020). Promise for whom? "Free-college" programs and enrollments by race and gender classifications at public, 2-year colleges. Educational Evaluation and Policy Analysis, 42(4), 603-627.

Giles, D. (March 24, 2011). Dummies for dummies. Econometrics Beat: Dave Giles' Blog. https://davegiles.blogspot.com/2011/03/dummies-for-dummies.html\#more. Accessed on 3/7/2020.

Goodman-Bacon, A. (2018). Difference-in-differences with variation in treatment timing. National Bureau of Economic Research working paper 25018. https://www.nber.org/papers/w25018

Gonzalez, G., Bozick, R., Taylor, S., \& Phillips, A. (2011). Fulfilling the Pittsburgh Promise: Early progress of Pittsburgh's postsecondary scholarship program. Monograph. RAND Corporation: Santa Monica, CA.

Gurantz, O. (2020). What does free community college buy? Early impacts from the Oregon Promise. Journal of Policy Analysis and Management, 39(1), 11-35. https://doi.org/10.1002/pam.22157

Hemenway, B. (2018). The influence of early information on postsecondary affordability (Doctoral Dissertation, University of Illinois at Urbana-Champaign).

Hershbein, B. (2013). A second look at enrollment changes after the Kalamazoo Promise. W. E. Upjohn Institute for Employment Research. Working paper.

Jacob, B., McCall, B., \& Stange, K. M. (2018). College as country club: Do colleges cater to students' preferences for consumption? Journal of Labor Economics, (36)2, 309-348.

Jacobson, L. S., LaLonde, R. J., \& Sullivan, D. G. (1993). Earnings losses of displaced workers. American Economic Review, 685-709.

Jaquette, O. \& Parra, E. (2016). The problem with the Delta Cost Project database. Research in Higher Education, 57: 630-651.

Jones, J. N., Miron, G., \& Kelaher-Young, A. J. (2012). The Kalamazoo promise and perceived changes in teacher beliefs, expectations, and behaviors. The Journal of Educational Research, 105(1), 36-51.

LeGower, M. \& Walsh, R. (2017). Promise scholarship programs as place-making policy: Evidence from school enrollment and housing prices. Journal of Urban Economics, 101(C), 74-89.

Leslie, L. L., Slaughter, S., Taylor, B. J., \& Zhang, L. (2012). How do revenue variations affect 
expenditures within US research universities? Research in Higher Education, 53(6), pp. 614-639.

Long, B. T. (2004). How do financial aid policies affect colleges? The institutional impact of the Georgia HOPE scholarship. Journal of Human Resources, 39(4), 1045-1066.

Mack, J. (2014, Nov. 24). Latest Kalamazoo Promise data reflects program's successes, challenges. Mlive.com. Retrieved from http://www.mlive.com/news/kalamazoo/index.ssf/2014/11/latest_kalamazoo promise da ta.html

Mapquest. (2015). [Graphic illustration]. Directions. Available from: http://www.mapquest.com/directions

Mattern, K. \& Wyatt, J. N. (2009) Student choice of college: How far do students go for an education? Journal of College Admission, 203, 18-29.

Miller-Adams, Michelle. (2010). "The Kalamazoo Promise: Building Assets for Community Change." Presentation slides. Kalamazoo, MI: W. E. Upjohn Institute. http://research.upjohn.org/presentations/4 Accessed 7/24/2016.

Miller-Adams, M. (2011). The value of universal eligibility in promise scholarship programs. Employment Research Newsletter, 18(4), 1.

Miller-Adams, M. (2015). Promise nation: Transforming communities through place-based scholarship. W.E. Upjohn Institute for Research and Employment: Kalamazoo, MI.

Miron, G., Jones, J. \& Kelaher-Young, A. (2011). The Kalamazoo Promise and perceived changes in school climate. Education Policy Analysis Archives, 19(7), 1-21.

Miron, G., Jones, J. \& Kelaher-Young, A. (2012). The impact of the Kalamazoo Promise on student attitudes, goals, and aspirations. American Secondary Education, 40(2), 5-27.

Page, L. C., Iriti, J., Lowry, D., \& Anthony, A. (2017). The promise of place-based investment in college access and success: Investigating the impact of the Pittsburgh Promise SSRN working paper. http://dx.doi.org/10.2139/ssrn.3071727

Perna, L. W., \& Leigh, E. W. (2018). Understanding the promise: A typology of state and local college promise programs. Educational Researcher, 47(3), 155-180. https://doi.org/10.3102/0013189X17742653

Perna, L. W., \& Leigh, E. W. (n.d.) [database] Database of college promise programs. Philadelphia, PA: University of Pennsylvania, Alliance for Higher Education and Democracy. Retrieved from http://ahead-penn.org/creating-knowledge/college-promise.

Perna, L. W., Wright-Kim, J., \& Leigh, E. W. (2020). Is a college promise program an effective use of resources? Understanding the implications of program design and resource investments for equity and efficiency. AERA Open. https://doi.org/10.1177/2332858420967633

Pfeffer, J. \& Salancik, G. (1978). The external control of organizations: A resource dependency perspective. New York, NY: Harper and Row.

Pluhta, E. A., \& Penny, G. R. (2013). The effect of a community college promise scholarship on access and success. Community College Journal of Research and Practice, 37(10), 723 734.

Powell, F. (February 1, 2018). These states offer tuition-free college programs. U.S. News and World Report. https://www.usnews.com/education/best-colleges/paying-forcollege/articles/2018-02-01/these-states-offer-tuition-free-college-programs Accessed $7 / 19 / 2018$. 
Sentz, R., Metsker, M., Linares, P. \& Clemans, J. (n.d.). How your school affects where you live. Emsi. https://economicmodeling.com/how-your-school-affects-where-you-live/

Singell, L., Waddell, G., \& Curs, B. (2006). HOPE for the Pell? Institutional Effects in the Intersection of Merit-Based and Need-Based Aid. Southern Economic Journal, 73(1), 7999. doi:10.2307/20111875

Slaughter, S., \& Leslie, L. L. (1999). Academic capitalism: Politics, policies, and the entrepreneurial university. Baltimore, MD: Johns Hopkins University Press.

Slaughter, S., \& Rhoades, G. (2009). Academic capitalism and the new economy. Baltimore, MD: Johns Hopkins University Press.

Sohn, H., Rubenstein, R., Murchie, J., \& Bifulco, R. (2017). Assessing the effects of place-based scholarships on urban revitalization: The case of Say Yes to Education. Educational Evaluation and Policy Analysis, 39(2), 198-222.

Sjoquist, D. L. \& Winters, J. V. (2015). State Merit-Based Financial Aid Programs and College Attainment. Journal of Regional Science, 55(3), 364-390. https://doi.org/10.1111/jors.12161

Swanson, E., Watson, A., \& Ritter, G. W.(2020). Promises fulfilled? A systematic review of the impacts of promise programs. In L. W. Perna \& E. J. Smith (Eds). Improving ResearchBased Knowledge of College Promise Programs. American Educational Research Association Press.

Tennessee Promise. (n.d.). http://tnpromise.gov/Accessed February 21, 2017.

W. E. Upjohn Institute for Employment Research. (2016). Enrollment of Kalamazoo Promise Recipients at Local Institutions [Data chart]. Retrieved from: http://www.upjohn.org/sites/default/files/promise/8-enrollment-2014.pdf Accessed 7/22/2016.

W. E. Upjohn Institute for Employment Research (n.d.). [database] Interactive database of placebased or "Promise" scholarship programs. https://www.upjohn.org/promise/

Wooldridge, J. M. (2002). Econometric analysis of cross-section and panel data. Cambridge, MA: MIT Press. 
Figure 1: Institutional Expenditures for Instruction Hypothesis within a Difference-in-Difference Model

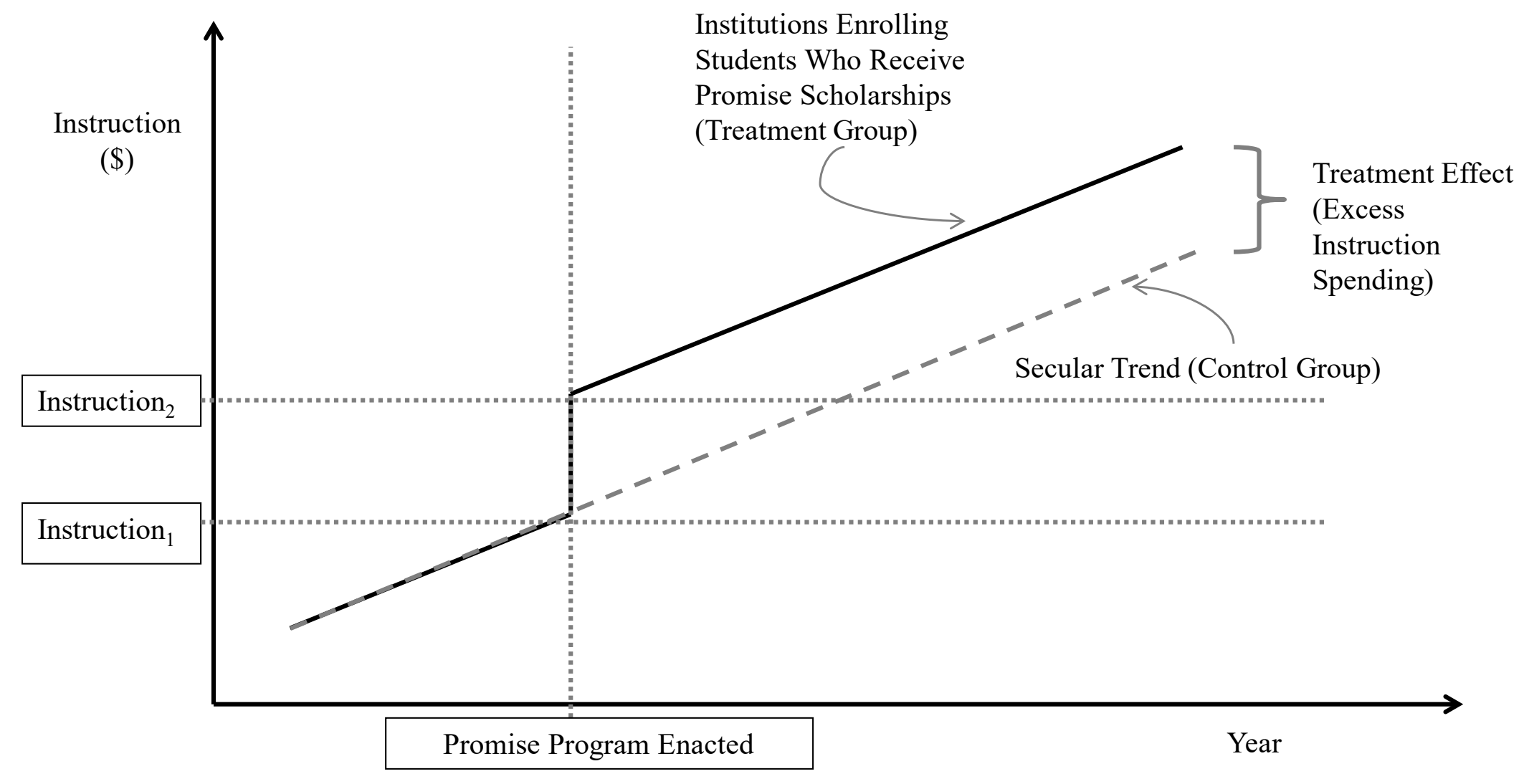


Figure 2: Time Relative to Implementation of a Promise Program Current Year Expenditures for Instruction (logged, CPI adjusted)

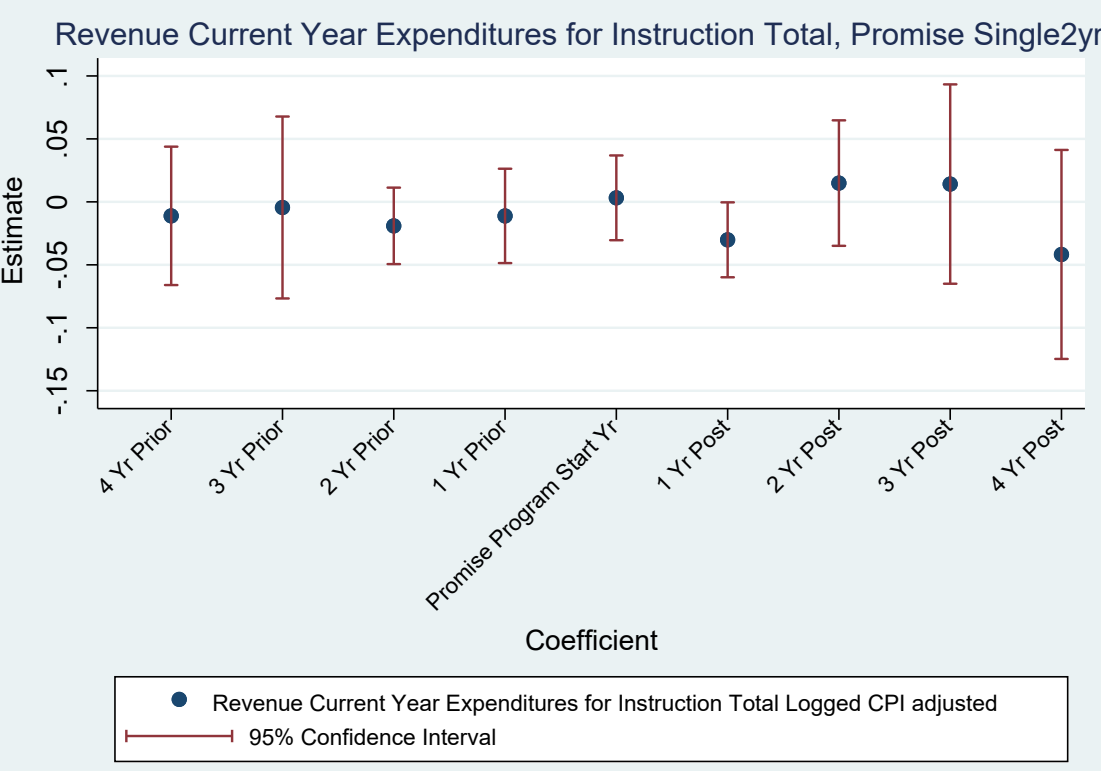

Revenue Current Year Expenditures for Instruction Total, Promise Nearest2yr

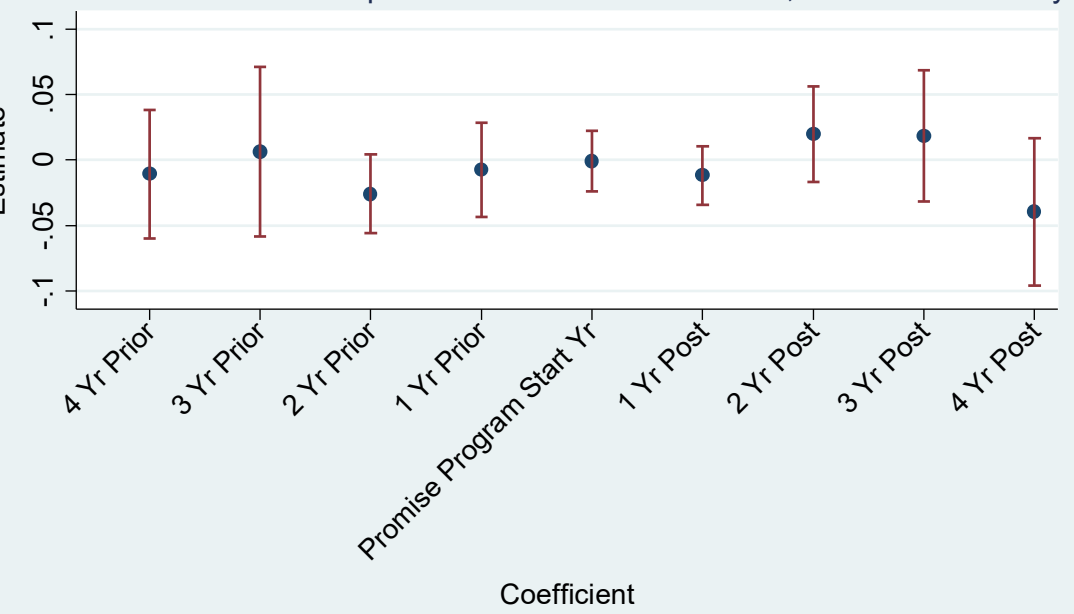

95\% Confidence Interv

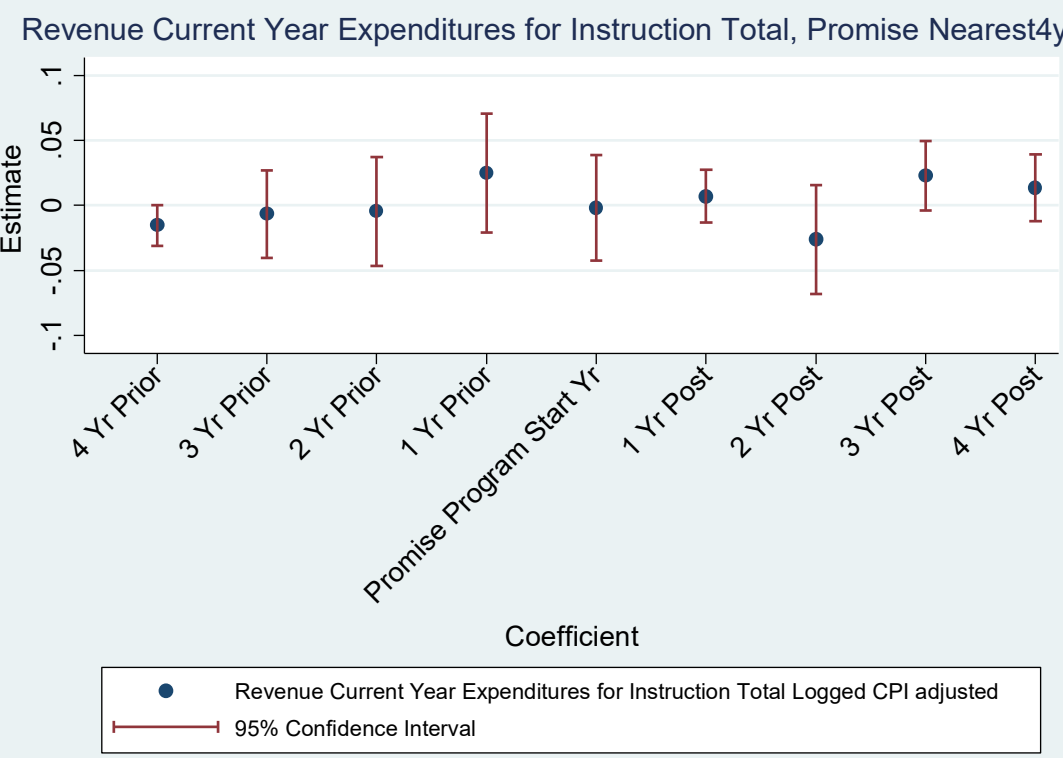


Table 1: Descriptive Statistics, 2000-2014

Variable

Promise Single2yr

Promise Single4yr

Promise Nearest4yr (logged and CPI adjusted)

Current Year Expenditures for Instruction Total

(logged and CPI adjusted)

Current Year Expenditures for Academic Support Total (logged and CPI adjusted)

Current Year Expenditures for Student Services Total (logged and CPI adjusted)

Current Year Expenditures for Public Services Total (logged and CPI adjusted)

Current Year Expenditures for Institutional Support Total (logged and CPI adjusted)

Current Year Expenditures for Auxiliary Enterprises Total (logged and CPI adjusted)

Instruction Share of Education and Related Expenses

Academic and Institutional Support and Operations and

Maintenance Share of Education and Related Expenses

Public Service Share of Education and Related Expenses

Total Enrollment

(logged)

State and Local Appropriations

(logged and CPI adjusted)

Total Current Funds Revenues

(logged and CPI adjusted)
Mean Std. Dev. Min Max Observations

\begin{tabular}{l|l|l|l|l|l|l|}
\hline overall & 0.01 & 0.09 & 0.00 & 1.00 & $\mathrm{~N}=19822$ \\
\hline
\end{tabular}

\begin{tabular}{|l|l|l|l|l|}
\hline between & 0.07 & 0.00 & 0.93 & $\mathrm{n}=1330$ \\
\hline
\end{tabular}

within

overall

between

within

overall

between

within

overall

between

within

overall

between

within

overall

between

within

overall

\begin{tabular}{ll|l|l|l|l|}
0.01 & 0.12 & 0.00 & $1.00 \mathrm{~N}=19822$ \\
\hline
\end{tabular}

\begin{tabular}{l|l|l|l|l}
0.06 & -0.92 & 0.94 & T-bar $=14.9038$ \\
\hline
\end{tabular}

\begin{tabular}{|l|l|l|l|l|}
0.09 & 0.00 & $1.00 \mathrm{n}=1330$
\end{tabular}

\begin{tabular}{l|r|r|r|}
0.08 & -0.92 & 0.95 & T-bar $=14.9038$ \\
\hline
\end{tabular}

\begin{tabular}{ll|l|l|l|l|l}
0.00 & 0.03 & 0.00 & $1.00 \mathrm{~N}=19822$
\end{tabular}

\begin{tabular}{|l|l|l|l|}
0.02 & 0.00 & 0.47 & $\mathrm{n}=1330$
\end{tabular}

\begin{tabular}{l|r|r|r|}
0.02 & -0.47 & 0.80 & T-bar $=14.9038$ \\
\hline
\end{tabular}

\begin{tabular}{|l|l|l|l|l|}
\hline 0.01 & 0.08 & 0.00 & $1.00 \mathrm{~N}=19822$ \\
\hline
\end{tabular}

\begin{tabular}{|r|r|r|r|}
\hline 0.06 & 0.00 & $1.00 \mathrm{n}=1330$ \\
\hline
\end{tabular}

\begin{tabular}{r|r|r|r|}
\hline 0.05 & -0.79 & 0.94 & T-bar $=14.9038$ \\
\hline
\end{tabular}

\begin{tabular}{|l|r|r|r|r|}
\hline 1.90 & 1.21 & 9.94 & 22.80 & $\mathrm{~N}=19791$ \\
\hline
\end{tabular}

\begin{tabular}{|l|l|l|l|l|}
1.20 & 14.76 & 22.59 & $\mathrm{n}=1330$
\end{tabular}

\begin{tabular}{r|r|r|r|r}
0.17 & 11.46 & 19.93 & T-bar $=14.8805$ \\
\hline 1.19 & 8.87 & 22.03 & N $=19776$
\end{tabular}

\begin{tabular}{|r|r|r|r|r|}
\hline 1.02 & 1.19 & 8.87 & 22.03 & $\mathrm{~N}=19776$ \\
\hline
\end{tabular}

\begin{tabular}{l|l|l|l|l|}
1.18 & 14.07 & 21.75 & $\mathrm{n}=1329$
\end{tabular}

\begin{tabular}{|l|r|r|l|}
0.17 & 10.61 & 18.65 & T-bar $=14.8804$ \\
\hline 1.39 & 7.22 & 20.32 & $\mathrm{~N}=19754$
\end{tabular}

\begin{tabular}{ll|l|l|l|l|l}
15.38 & 1.39 & 7.22 & $20.32 \mathrm{~N}=19754$
\end{tabular}

\begin{tabular}{|l|l|l|l|l|l|}
\hline between & 1.37 & 10.39 & 19.90 & $\mathrm{n}=1329$ \\
\hline
\end{tabular}

\begin{tabular}{|l|l|l|l|l|l|}
\hline within & 0.26 & 9.33 & 17.38 & T-bar $=14.8638$ \\
\hline
\end{tabular}

\begin{tabular}{|l|r|r|r|r|r|}
\hline overall & 15.48 & 1.12 & 7.68 & 19.72 & $\mathrm{~N}=19787$ \\
\hline
\end{tabular}

\begin{tabular}{|l|r|r|r|r|}
\hline between & 1.09 & 10.80 & 19.50 & $\mathrm{n}=1330$ \\
\hline
\end{tabular}

\begin{tabular}{|l|l|l|l|l|} 
within & 0.25 & 9.35 & 16.95 & T-bar $=14.8774$ \\
\hline
\end{tabular}

\begin{tabular}{|l|r|r|r|r|r|r|}
\hline overall & 14.01 & 2.31 & 1.39 & 20.35 & $\mathrm{~N}=14789$ \\
\hline
\end{tabular}

\begin{tabular}{|l|l|l|l|l|l|}
\hline between & 2.42 & 5.14 & 19.98 & $\mathrm{n}=1112$ \\
\hline
\end{tabular}

within

overall

\begin{tabular}{l|l|l|l|l|}
0.70 & 5.65 & 20.84 & T-bar $=13.2995$ \\
\hline
\end{tabular}

\begin{tabular}{|l|l|r|r|r|}
15.89 & 1.11 & 7.95 & 20.61 & $\mathrm{~N}=19790$ \\
\hline
\end{tabular}

\begin{tabular}{|l|l|l|l|l|}
\hline between & 1.09 & 11.35 & 20.14 & $\mathrm{n}=1330$ \\
\hline
\end{tabular}

within

\begin{tabular}{l|l|l|l|l}
0.24 & 9.11 & 17.82 & T-bar $=14.8797$ \\
\hline 1.91 & 1.45 & 20.86 & $\mathrm{~N}=18086$
\end{tabular}

\begin{tabular}{|l|l|l|l|l|l|}
\hline overall & 15.27 & 1.91 & 1.45 & 20.86 & $\mathrm{~N}=18086$ \\
\hline
\end{tabular}

\begin{tabular}{|l|r|r|r|r|}
\hline between & 1.91 & 6.93 & 20.18 & $\mathrm{n}=1275$ \\
\hline
\end{tabular}

\begin{tabular}{|l|r|r|r|r|}
\hline within & 0.54 & 6.75 & 21.98 & T-bar $=14.1851$ \\
\hline
\end{tabular}

\begin{tabular}{|l|l|l|l|l|l|l|}
\hline overall & 0.52 & 0.08 & 0.06 & 0.88 & $\mathrm{~N}=19776$ \\
\hline
\end{tabular}

\begin{tabular}{|l|l|l|l|l|}
\hline between & 0.08 & 0.21 & 0.78 & $\mathrm{n}=1329$ \\
\hline
\end{tabular}

within

overall

\begin{tabular}{l|l|l|l|l|}
0.04 & 0.21 & 0.85 & T-bar $=14.8804$ \\
\hline
\end{tabular}

\begin{tabular}{|l|l|l|l|l|l|l|l|}
\hline overall & 0.12 & 0.05 & 0.00 & $0.49 \mathrm{~N}=19787$ \\
\hline
\end{tabular}

\begin{tabular}{|l|l|l|l|l|l|}
\hline between & 0.04 & 0.01 & 0.35 & $\mathrm{n}=1330$ \\
\hline
\end{tabular}

within

overall

\begin{tabular}{|r|r|r|r|}
0.02 & -0.15 & 0.35 & T-bar $=14.8774$ \\
\hline
\end{tabular}

between

0.36

\begin{tabular}{l|l|l|l|l|}
0.08 & 0.09 & 0.92 & $\mathrm{~N}=19791$ \\
\hline
\end{tabular}

within

\begin{tabular}{|l|l|l|l|l|}
0.07 & 0.17 & 0.89 & $\mathrm{n}=1330$
\end{tabular}

overall

\begin{tabular}{|l|l|l|l|}
0.04 & 0.04 & 0.79 & T-bar $=14.8805$ \\
\hline
\end{tabular}

between

within

overall

between

within

overall

between

within

overall

between

within

overall

between

within

\begin{tabular}{l|l|l|l|l|}
0.06 & 0.07 & 0.00 & $0.51 \mathrm{~N}=14789$
\end{tabular}

\begin{tabular}{l|l|l|l|l|}
0.06 & 0.00 & $0.45 \mathrm{n}=1112$ \\
\hline
\end{tabular}

\begin{tabular}{l|l|l|l}
0.03 & -0.22 & 0.32 & T-bar $=13.2995$ \\
\hline
\end{tabular}

\begin{tabular}{ll|l|l|l|l|l|}
0.10 & 0.14 & 0.00 & 0.83 & $\mathrm{~N}=7680$
\end{tabular}

\begin{tabular}{l|l|l|l|l|}
0.13 & 0.00 & $0.74 \mathrm{n}=629$
\end{tabular}

\begin{tabular}{|l|r|r|r|}
0.02 & -0.17 & 0.76 & T-bar $=12.2099$ \\
\hline
\end{tabular}

\begin{tabular}{|l|r|r|r|r|}
\hline 8.70 & 1.03 & 4.89 & 12.52 & $\mathrm{~N}=19803$ \\
\hline
\end{tabular}

\begin{tabular}{|l|r|r|r|}
1.02 & 5.49 & $12.37 \mathrm{n}=1330$
\end{tabular}

\begin{tabular}{l|l|l|l|l|}
0.16 & 6.38 & 10.09 & T-bar $=14.8895$ \\
\hline
\end{tabular}

\begin{tabular}{|l|l|l|l|l|}
17.13 & 1.14 & 2.54 & 21.49 & $\mathrm{~N}=19494$ \\
\hline
\end{tabular}

\begin{tabular}{|l|l|l|l|l|}
1.15 & 9.82 & $21.36 \mathrm{n}=1330$
\end{tabular}

\begin{tabular}{r|r|r|r|}
0.23 & 5.29 & 20.72 & T-bar $=14.6571$ \\
\hline
\end{tabular}

\begin{tabular}{|l|l|r|r|l|}
\hline 8.07 & 1.25 & 10.09 & 23.18 & $\mathrm{~N}=19791$
\end{tabular}

\begin{tabular}{|l|l|l|l|l|}
1.24 & 14.90 & 22.93 & $\mathrm{n}=1330$
\end{tabular}

\begin{tabular}{l|l|l|l|}
0.17 & 11.69 & 19.81 & T-bar $=14.8805$ \\
\hline
\end{tabular} 


\begin{tabular}{|c|c|c|c|c|c|c|c|c|c|c|c|c|}
\hline & (1) & (2) & (3) & (4) & $(5)$ & (6) & (7) & $(8)$ & (9) & (10) & (11) & (12) \\
\hline & \multicolumn{6}{|c|}{ Student-Related } & \multicolumn{6}{|c|}{ Non-Student-Related } \\
\hline & \multicolumn{2}{|c|}{ Instruction Total (Logged) } & \multicolumn{2}{|c|}{$\begin{array}{l}\text { Academic Support Total } \\
\text { (Logged) }\end{array}$} & \multicolumn{2}{|c|}{$\begin{array}{l}\text { Student Services Total } \\
\text { (Logged) }\end{array}$} & \multicolumn{2}{|c|}{$\begin{array}{l}\text { Public Service Total } \\
\text { (Logged) }\end{array}$} & \multicolumn{2}{|c|}{$\begin{array}{l}\text { Institutional Support Total } \\
\text { (Logged) }\end{array}$} & \multicolumn{2}{|c|}{$\begin{array}{l}\text { Auxiliary Enterprises Total } \\
\text { (Logged) }\end{array}$} \\
\hline VARIABLES & $\begin{array}{l}\text { Promise } \\
\text { Single2yr }\end{array}$ & $\begin{array}{c}\text { Promise } \\
\text { Nearest2yr } \\
\end{array}$ & $\begin{array}{c}\text { Promise } \\
\text { Single2yr } \\
\end{array}$ & $\begin{array}{c}\text { Promise } \\
\text { Nearest2yr }\end{array}$ & $\begin{array}{l}\text { Promise } \\
\text { Single2yr } \\
\end{array}$ & $\begin{array}{c}\text { Promise } \\
\text { Nearest2yr } \\
\end{array}$ & $\begin{array}{l}\text { Promise } \\
\text { Single2yr }\end{array}$ & $\begin{array}{c}\text { Promise } \\
\text { Nearest2yr }\end{array}$ & $\begin{array}{l}\text { Promise } \\
\text { Single2yr }\end{array}$ & $\begin{array}{c}\text { Promise } \\
\text { Nearest2yr }\end{array}$ & $\begin{array}{c}\text { Promise } \\
\text { Single2yr } \\
\end{array}$ & $\begin{array}{c}\text { Promise } \\
\text { Nearest2yr } \\
\end{array}$ \\
\hline \multirow[t]{2}{*}{ Promise Single2yr } & -0.0282 & & 0.0225 & & $-0.143^{* * *}$ & & $-0.330 * *$ & & 0.0282 & & 0.124 & \\
\hline & $(0.0193)$ & & $(0.0445)$ & & $(0.0384)$ & & $(0.148)$ & & $(0.0298)$ & & $(0.0814)$ & \\
\hline \multirow[t]{2}{*}{ Promise Nearest $2 \mathrm{yr}$} & & $-0.0327 * *$ & & 0.00635 & & $-0.0888 * * *$ & & $-0.464 * * *$ & & 0.00334 & & $0.176^{*}$ \\
\hline & & $(0.0139)$ & & $(0.0423)$ & & $(0.0308)$ & & $(0.126)$ & & $(0.0265)$ & & $(0.0902)$ \\
\hline Total Enrollment & $0.145^{* * *}$ & $0.145^{* * *}$ & 0.0763 & 0.0761 & $0.109 * *$ & $0.110^{* *}$ & 0.0260 & 0.0337 & -0.00423 & -0.00441 & 0.0396 & 0.0390 \\
\hline (logged, one year lag) & $(0.0416)$ & $(0.0416)$ & $(0.0546)$ & $(0.0546)$ & $(0.0502)$ & $(0.0501)$ & $(0.156)$ & $(0.156)$ & $(0.0480)$ & $(0.0480)$ & $(0.0848)$ & $(0.0848)$ \\
\hline State and Local Appropriations & 0.00296 & 0.00299 & 0.0232 & 0.0232 & -0.00614 & -0.00600 & 0.100 & 0.100 & $0.164 * * *$ & $0.164 * * *$ & 0.0560 & 0.0559 \\
\hline (logged, one year lag, CPI adjusted) & $(0.0246)$ & $(0.0246)$ & $(0.0215)$ & $(0.0215)$ & $(0.0216)$ & $(0.0216)$ & $(0.0961)$ & $(0.0960)$ & $(0.0548)$ & $(0.0548)$ & $(0.118)$ & $(0.118)$ \\
\hline Total Current Funds Revenues & $0.653 * * *$ & $0.653 * * *$ & $0.608 * * *$ & $0.608 * * *$ & $0.644 * * *$ & $0.644 * * *$ & $0.692 * * *$ & $0.691 * * *$ & $0.565 * * *$ & $0.565 * * *$ & $0.877 * * *$ & $0.878 * * *$ \\
\hline (logged, one year lag, CPI adjusted) & $(0.0893)$ & $(0.0893)$ & $(0.0906)$ & $(0.0906)$ & $(0.0921)$ & $(0.0920)$ & $(0.162)$ & $(0.162)$ & $(0.0903)$ & $(0.0904)$ & $(0.125)$ & $(0.125)$ \\
\hline \multirow[t]{2}{*}{ Constant } & $3.686^{* * *}$ & $3.682 * * *$ & $4.824 * * *$ & $4.828 * * *$ & $4.280 * * *$ & $4.259 * * *$ & -1.108 & -1.143 & $2.966^{* *}$ & $2.971 * *$ & $-2.656^{*}$ & $-2.664 *$ \\
\hline & $(1.336)$ & $(1.335)$ & $(1.389)$ & $(1.389)$ & $(1.406)$ & $(1.404)$ & $(2.448)$ & $(2.447)$ & $(1.225)$ & $(1.226)$ & $(1.561)$ & $(1.561)$ \\
\hline Institution Fixed Effects? & Yes & Yes & Yes & Yes & Yes & Yes & Yes & Yes & Yes & Yes & Yes & Yes \\
\hline Year Fixed Effects? & Yes & Yes & Yes & Yes & Yes & Yes & Yes & Yes & Yes & Yes & Yes & Yes \\
\hline State-Specific Linear Time Trends? & Yes & Yes & Yes & Yes & Yes & Yes & Yes & Yes & Yes & Yes & Yes & Yes \\
\hline Observations & 11,209 & 11,209 & 11,175 & 11,175 & 11,207 & 11,207 & 7,057 & 7,057 & 11,209 & 11,209 & 9,706 & 9,706 \\
\hline R-squared & 0.605 & 0.605 & 0.252 & 0.252 & 0.393 & 0.393 & 0.065 & 0.068 & 0.408 & 0.408 & 0.102 & 0.103 \\
\hline Number of Institutions & 841 & 841 & 840 & 840 & 841 & 841 & 622 & 622 & 841 & 841 & 787 & 787 \\
\hline
\end{tabular}

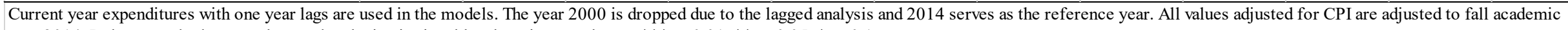
year 2014. Robust standard errors clustered at the institutional level are in parentheses. ${ }^{* * *} \mathrm{p}<0.01,{ }^{* *} \mathrm{p}<0.05,{ }^{*} \mathrm{p}<0.1$ 
Table 3: Difference-in-Difference Models for Promise Programs at Four-Year Institutions and Current Year Expenditures, Using Nearest Neighbor Model Specifications, 2000-2014

\begin{tabular}{|c|c|c|c|c|c|c|}
\hline & $(1)$ & $(2)$ & (3) & (4) & $(5)$ & $(6)$ \\
\hline & \multicolumn{3}{|c|}{ Student-Related } & \multicolumn{3}{|c|}{ Non-Student-Related } \\
\hline & $\begin{array}{l}\text { Instruction } \\
\text { Total } \\
\text { (Logged) }\end{array}$ & $\begin{array}{l}\text { Academic } \\
\text { Support } \\
\text { Total } \\
\text { (Logged) }\end{array}$ & $\begin{array}{c}\text { Student } \\
\text { Services } \\
\text { Total } \\
\text { (Logged) }\end{array}$ & $\begin{array}{c}\text { Public } \\
\text { Service Total } \\
\text { (Logged) }\end{array}$ & $\begin{array}{l}\text { Institutional } \\
\text { Support } \\
\text { Total } \\
\text { (Logged) }\end{array}$ & $\begin{array}{c}\text { Auxiliary } \\
\text { Enterprises } \\
\text { Total } \\
\text { (Logged) }\end{array}$ \\
\hline VARIABLES & $\begin{array}{c}\text { Promise } \\
\text { Nearest4yr }\end{array}$ & $\begin{array}{c}\text { Promise } \\
\text { Nearest4yr }\end{array}$ & $\begin{array}{c}\text { Promise } \\
\text { Nearest4yr }\end{array}$ & $\begin{array}{c}\text { Promise } \\
\text { Nearest4yr }\end{array}$ & $\begin{array}{c}\text { Promise } \\
\text { Nearest4yr }\end{array}$ & $\begin{array}{l}\text { Promise } \\
\text { Nearest4yr }\end{array}$ \\
\hline \multirow[t]{2}{*}{ Promise Nearest 4 yr } & -0.0257 & -0.118 & 0.00140 & $0.136^{*}$ & 0.0362 & -0.0234 \\
\hline & $(0.0242)$ & $(0.119)$ & $(0.0219)$ & $(0.0780)$ & $(0.0505)$ & $(0.0597)$ \\
\hline Total Enrollment & $0.313 * * *$ & $0.231 * * *$ & $0.321 * * *$ & -0.237 & 0.0565 & $0.444 * * *$ \\
\hline (logged, one year lag) & $(0.0348)$ & $(0.0487)$ & $(0.0486)$ & $(0.171)$ & $(0.0517)$ & $(0.164)$ \\
\hline State and Local Appropriations & $0.0873 * * *$ & $0.105 * * *$ & $0.0409^{*}$ & -0.000780 & 0.0637 & $-0.0941^{*}$ \\
\hline (logged, one year lag, CPI adjusted) & $(0.0188)$ & $(0.0339)$ & $(0.0239)$ & $(0.0860)$ & $(0.0395)$ & $(0.0545)$ \\
\hline Total Current Funds Revenues & $0.429 * * *$ & $0.411 * * *$ & $0.374 * * *$ & $0.974 * * *$ & $0.618 * * *$ & $0.791 * * *$ \\
\hline (logged, one year lag, CPI adjusted) & $(0.0489)$ & $(0.0574)$ & $(0.0460)$ & $(0.163)$ & $(0.0547)$ & $(0.120)$ \\
\hline \multirow[t]{2}{*}{ Constant } & $5.444 * * *$ & $4.957 * * *$ & $5.650 * * *$ & -0.823 & $3.391 * * *$ & -1.109 \\
\hline & $(0.749)$ & $(0.956)$ & $(0.823)$ & $(3.105)$ & $(1.001)$ & $(2.477)$ \\
\hline Institution Fixed Effects? & Yes & Yes & Yes & Yes & Yes & Yes \\
\hline Year Fixed Effects? & Yes & Yes & Yes & Yes & Yes & Yes \\
\hline State-Specific Linear Time Trends? & Yes & Yes & Yes & Yes & Yes & Yes \\
\hline Observations & 6,978 & 6,992 & 6,992 & 6,600 & 6,992 & 6,936 \\
\hline R-squared & 0.749 & 0.430 & 0.623 & 0.064 & 0.433 & 0.290 \\
\hline Number of Institutions & 540 & 541 & 541 & 507 & 541 & 538 \\
\hline
\end{tabular}


Table 4: Difference-in-Difference Models for Promise Programs at Two-Year Institutions Share of Expenditures, Using Single Institution and Nearest Neighbor Model Specifications, 2000-2014

\begin{tabular}{|c|c|c|c|c|c|c|c|c|}
\hline & (1) & $(2)$ & (3) & (4) & $(5)$ & (6) & $(7)$ & (8) \\
\hline & \multicolumn{4}{|c|}{ Student-Related } & \multicolumn{4}{|c|}{ Non-Student-Related } \\
\hline & \multicolumn{2}{|c|}{$\begin{array}{c}\text { Instruction Share of } \\
\text { Education and Related } \\
\text { Expenses }\end{array}$} & \multicolumn{2}{|c|}{$\begin{array}{c}\text { Student Services Share of } \\
\text { Education and Related } \\
\text { Expenses }\end{array}$} & \multicolumn{2}{|c|}{$\begin{array}{c}\text { Academic and Institutional } \\
\text { Support and Operations and } \\
\text { Maintenance Share of } \\
\text { Education and Related } \\
\text { Expenses }\end{array}$} & \multicolumn{2}{|c|}{$\begin{array}{c}\text { Public Service-Related } \\
\text { Share of Expenses }\end{array}$} \\
\hline VARIABLES & $\begin{array}{l}\text { Promise } \\
\text { Single } 2 \mathrm{yr}\end{array}$ & $\begin{array}{c}\text { Promise } \\
\text { Nearest2yr }\end{array}$ & $\begin{array}{l}\text { Promise } \\
\text { Single } 2 \mathrm{yr}\end{array}$ & $\begin{array}{c}\text { Promise } \\
\text { Nearest2yr }\end{array}$ & $\begin{array}{c}\text { Promise } \\
\text { Single } 2 \mathrm{yr} \\
\end{array}$ & $\begin{array}{c}\text { Promise } \\
\text { Nearest2yr }\end{array}$ & $\begin{array}{l}\text { Promise } \\
\text { Single } 2 \mathrm{yr} \\
\end{array}$ & $\begin{array}{c}\text { Promise } \\
\text { Nearest } 2 \mathrm{yr}\end{array}$ \\
\hline \multirow[t]{2}{*}{ Promise Single $2 y r$} & -0.00537 & & $-0.0159 * * *$ & & $0.0213 * * *$ & & -0.00184 & \\
\hline & $(0.00547)$ & & $(0.00587)$ & & $(0.00602)$ & & $(0.00451)$ & \\
\hline \multirow[t]{2}{*}{ Promise Nearest2yr } & & -0.00447 & & $-0.00815 *$ & & $0.0127 * *$ & & -0.00252 \\
\hline & & $(0.00430)$ & & $(0.00454)$ & & $(0.00564)$ & & $(0.00377)$ \\
\hline Total Enrollment & $0.0195 * * *$ & $0.0195 * * *$ & 0.000643 & 0.000756 & $-0.0201 * * *$ & $-0.0202 * * *$ & -0.00845 & -0.00841 \\
\hline (logged, one year lag) & $(0.00703)$ & $(0.00704)$ & $(0.00391)$ & $(0.00391)$ & $(0.00668)$ & $(0.00669)$ & $(0.00597)$ & $(0.00597)$ \\
\hline State and Local Appropriations & -0.0102 & -0.0102 & -0.00402 & -0.00401 & $0.0140 * * *$ & $0.0140 * * *$ & 0.00307 & 0.00307 \\
\hline (logged, one year lag, CPI adjusted) & $(0.00624)$ & $(0.00624)$ & $(0.00253)$ & $(0.00252)$ & $(0.00494)$ & $(0.00495)$ & $(0.00450)$ & $(0.00450)$ \\
\hline Total Current Funds Revenues & 0.00366 & 0.00368 & 0.000438 & 0.000505 & -0.00471 & -0.00479 & 0.00574 & 0.00573 \\
\hline (logged, one year lag, CPI adjusted) & $(0.00778)$ & $(0.00778)$ & $(0.00378)$ & $(0.00378)$ & $(0.00700)$ & $(0.00700)$ & $(0.00820)$ & $(0.00820)$ \\
\hline \multirow[t]{2}{*}{ Constant } & $0.223 * *$ & $0.222 * *$ & $0.256 * * *$ & $0.253 * * *$ & $0.535 * * *$ & $0.538 * * *$ & -0.0387 & -0.0389 \\
\hline & $(0.104)$ & $(0.104)$ & $(0.0618)$ & $(0.0620)$ & $(0.107)$ & $(0.107)$ & $(0.110)$ & $(0.109)$ \\
\hline Institution Fixed Effects? & Yes & Yes & Yes & Yes & Yes & Yes & Yes & Yes \\
\hline Year Fixed Effects? & Yes & Yes & Yes & Yes & Yes & Yes & Yes & Yes \\
\hline State-Specific Linear Time Trends? & Yes & Yes & Yes & Yes & Yes & Yes & Yes & Yes \\
\hline Observations & 11,209 & 11,209 & 11,207 & 11,207 & 11,209 & 11,209 & 7,057 & 7,057 \\
\hline R-squared & 0.060 & 0.060 & 0.058 & 0.056 & 0.061 & 0.060 & 0.136 & 0.136 \\
\hline Number of Institutions & 841 & 841 & 841 & 841 & 841 & 841 & 622 & 622 \\
\hline
\end{tabular}


Table 5: Difference-in-Difference Models for Promise Programs at Four-Year Institutions Share of Expenditures, Using Nearest Neighbor Model Specifications, 2000-2014

\begin{tabular}{|c|c|c|c|c|c|}
\hline & (1) & $(2)$ & (3) & $(4)$ & $(5)$ \\
\hline & \multicolumn{2}{|c|}{ Student-Related } & \multicolumn{3}{|c|}{ Non-Student-Related } \\
\hline & $\begin{array}{l}\text { Instruction Share of } \\
\text { Education and } \\
\text { Related Expenses }\end{array}$ & $\begin{array}{c}\text { Student Services } \\
\text { Share of Education } \\
\text { and Related } \\
\text { Expenses }\end{array}$ & $\begin{array}{l}\text { Academic and } \\
\text { Institutional } \\
\text { Support and } \\
\text { Operations and } \\
\text { Maintenance Share } \\
\text { of Education and } \\
\text { Related Expenses }\end{array}$ & $\begin{array}{l}\text { Public Service- } \\
\text { Related Share of } \\
\text { Expenses }\end{array}$ & $\begin{array}{l}\text { Research-Related } \\
\text { Share of Expenses }\end{array}$ \\
\hline VARIABLES & $\begin{array}{c}\text { Promise } \\
\text { Nearest4yr }\end{array}$ & $\begin{array}{c}\text { Promise } \\
\text { Nearest4yr }\end{array}$ & $\begin{array}{c}\text { Promise } \\
\text { Nearest4yr }\end{array}$ & $\begin{array}{c}\text { Promise } \\
\text { Nearest4yr }\end{array}$ & $\begin{array}{c}\text { Promise } \\
\text { Nearest4yr }\end{array}$ \\
\hline \multirow[t]{2}{*}{ Promise Nearest 4 yr } & -0.00410 & 0.00169 & 0.00231 & 0.00655 & -0.00146 \\
\hline & $(0.00681)$ & $(0.00227)$ & $(0.00625)$ & $(0.00409)$ & $(0.00558)$ \\
\hline Total Enrollment & $0.0270 * *$ & 0.00600 & $-0.0316^{* * *}$ & $-0.0501 * * *$ & $-0.0240 * *$ \\
\hline (logged, one year lag) & $(0.0107)$ & $(0.00478)$ & $(0.0111)$ & $(0.0103)$ & $(0.00965)$ \\
\hline State and Local Appropriations & $7.83 e-05$ & -0.00396 & 0.00206 & -0.00229 & $-0.00912 * *$ \\
\hline (logged, one year lag, CPI adjusted) & $(0.00389)$ & $(0.00244)$ & $(0.00432)$ & $(0.00462)$ & $(0.00436)$ \\
\hline Total Current Funds Revenues & -0.00454 & -0.00523 & 0.0106 & $0.0360 * * *$ & $0.0350 * * *$ \\
\hline (logged, one year lag, CPI adjusted) & $(0.00946)$ & $(0.00401)$ & $(0.00979)$ & $(0.0101)$ & $(0.0119)$ \\
\hline \multirow[t]{2}{*}{ Constant } & $0.352 * *$ & $0.229 * * *$ & $0.425 * * *$ & -0.0858 & -0.268 \\
\hline & $(0.169)$ & $(0.0769)$ & $(0.152)$ & $(0.137)$ & $(0.169)$ \\
\hline Institution Fixed Effects? & Yes & Yes & Yes & Yes & Yes \\
\hline Year Fixed Effects? & Yes & Yes & Yes & Yes & Yes \\
\hline State-Specific Linear Time Trends? & Yes & Yes & Yes & Yes & Yes \\
\hline Observations & 6,978 & 6,992 & 6,992 & 6,600 & 6,055 \\
\hline R-squared & 0.126 & 0.184 & 0.139 & 0.131 & 0.087 \\
\hline Number of Institutions & 540 & 541 & 541 & 507 & 472 \\
\hline
\end{tabular}

One year lags are used in the models. The year 2000 is dropped due to the lagged analysis and 2014 serves as the reference year. All values adjusted for CPI are adjusted to fall academic year 2014. Robust standard errors clustered at the institutional level are in parentheses. ${ }^{* * *} \mathrm{p}<0.01,{ }^{* *} \mathrm{p}<0.05,{ }^{*} \mathrm{p}<0.1$ 


\section{Appendix A}

Appendix A presents results for models that match with promise program rules, but are less well-suited for use in DID models due to concerns over contamination in the control group. In the appendix we present results for three additional models: (1) promise programs that can be used at any 2-year institution statewide (State2yr), (2) all types of promise programs within a state that can be used at 2-year institutions (Single2yr + State2yr), and (3) promise programs that can be used at any 4-year institution (Single4yr + State4yr). The statewide models test effects of programs using all possible receiving institutions within the state where the promise program was created. ${ }^{13}$ This coding best matches the program rules for promise programs that can be used at institutions statewide. In these models, the control group is comprised of institutions in states without any promise programs. ${ }^{14}$ Due to small sample size (there are only two 4-year institutions in the Single4yr category), we have added the single and statewide 4-year programs into one measure. For consistency, we also run a combined model for 2-year institutions, Single $2 \mathrm{yr}$ + State2yr. Table 1A presents descriptive statistics for the treatment groups presented in the appendix. All of the other variables in the model are the same as in the main text and their descriptive statistics can be found in Table 1. Event study figures are available for each model from the authors upon request.

\section{Appendix Models Results}

Table 2A presents results for statewide, and combined single institution and statewide promise programs at 2-year institutions. We find negative effects of the introduction of promise programs on student-related expenditures. There are significant negative effects for both types of promise programs for academic support and student services $(\mathrm{p}<0.1$ or smaller). We find borderline negative, significant effects for total spending on academic support decreasing from 4.7-5.4\%. Following the introduction of a promise program, the magnitude of the decreases in student services spending are 6.1 and $6.2 \%$, respectively, as compared to 2 -year institutions that do not receive students with promise funds, all else equal.

Across the models, we find increases in spending across the non-student-related spending categories tested. We find significant increases in public service spending in the model of statewide promise programs $(\mathrm{p}<0.01)$, with a magnitude increase of $31.3 \%$. We find a positive, significant effect in the models of auxiliary expenditures $(\mathrm{p}<0.01)$. These expenditures increase by 30.6 and $24.4 \%$, respectively, for $2-y r$ institutions with promise funding.

\footnotetext{
${ }^{13}$ In addition to programs that specifically allow awards to be used at any in-state public postsecondary institution, we have included a few broad programs in our statewide category. These include programs that began with a regional scope (impacting more than two postsecondary institutions) and were later expanded to statewide programs. This applies to the three Tennessee programs - Ayers Foundation, Dyer County Promise Scholarship, and tnAchieves - that were later folded into the Tennessee Promise (Tennessee Promise, n.d.). We also include the Say Yes to Education programs, since these scholarships can be used at any SUNY or CUNY campus throughout the state of New York giving the programs statewide scope (even if technically not every public institution in the state is able to receive Promise students). Our coding only allows these programs to be used at institutions that are eligible based on program rules, but we categorize these programs as being in the statewide treatment group.

${ }^{14}$ A few programs, like the El Dorado Promise, allow Promise dollars to be used nationwide. For these programs we code the programs to restrict receipt to only institutions located in the state where the Promise program was created. This coding decision has the potential to create some "contamination" in the control group. However, given the importance of geography in enrollment decisions (Mattern \& Wyatt, 2009), we expect this to be a negligible amount for a small group of mobile, high achieving students whose rare presence at an out-of-state institution would be unlikely to influence institutional behavior.
} 
When considering student- and non-student-related spending at 4-year institutions (Table $3 \mathrm{~A}$ ), we do not find signification changes in spending levels for student-related expenditure categories. However, we do find significant changes $(\mathrm{p}<0.01)$ in non-student-related spending in two of the three categories tested. When considering institutional support, we find significant, positive increases in spending with a magnitude of $4.4 \%$. Auxiliary enterprises are likewise significantly impacted, but with a decline in spending of $11.1 \%(\mathrm{p}<0.01)$.

Tables $4 \mathrm{~A}$ and $5 \mathrm{~A}$ present results for the share of spending for 2- and 4-year institutions, respectively. In none of the models tested for either student- or non-student-related shares of expenditures do we find significant results for either 2- or 4-year institutions. In general, the results in the appendix support the findings in the main text. The introduction of promise programs alters spending levels with negative effects on student-related spending at 2-year institutions. In addition, there are differences in how institutions react to the introduction of a promise program between 2- and 4-year institutions. 
Table 1A: Descriptive Statistics for State and Single+State Model Specifications, 2000-2014

\begin{tabular}{|c|c|c|c|c|c|c|}
\hline Variable & & Mean & Std. Dev. & Min & Max & Observations \\
\hline \multirow{3}{*}{ Promise State2yr } & overall & 0.10 & 0.29 & 0.00 & 1.00 & $\mathrm{~N}=19822$ \\
\hline & between & & 0.24 & 0.00 & 1.00 & $\mathrm{n}=1330$ \\
\hline & within & & 0.17 & -0.70 & 0.96 & T-bar $=14.9038$ \\
\hline \multirow[t]{3}{*}{ Promise Single $2 \mathrm{yr}+$ State $2 \mathrm{yr}$} & overall & 0.10 & 0.30 & 0.00 & 1.00 & $\mathrm{~N}=19822$ \\
\hline & between & & 0.25 & 0.00 & 1.00 & $\mathrm{n}=1330$ \\
\hline & within & & 0.17 & -0.83 & 1.03 & T-bar $=14.9038$ \\
\hline \multirow[t]{3}{*}{ Promise State $4 y r$} & overall & 0.07 & 0.25 & 0.00 & 1.00 & $\mathrm{~N}=19822$ \\
\hline & between & & 0.20 & 0.00 & 1.00 & $\mathrm{n}=1330$ \\
\hline & within & & 0.15 & -0.73 & 1.00 & $\mathrm{~T}-$ bar $=14.9038$ \\
\hline \multirow[t]{3}{*}{ Promise Single $4 y r+$ State $4 y r$} & overall & 0.07 & 0.25 & 0.00 & 1.00 & $\mathrm{~N}=19822$ \\
\hline & between & & 0.20 & 0.00 & 1.00 & $\mathrm{n}=1330$ \\
\hline & within & & 0.15 & -0.73 & 1.00 & T-bar $=14.9038$ \\
\hline
\end{tabular}




\begin{tabular}{|c|c|c|c|c|c|c|c|c|c|c|c|c|}
\hline & (1) & (2) & (3) & (4) & (5) & (6) & (7) & (8) & (9) & (10) & (11) & $(12)$ \\
\hline & \multicolumn{6}{|c|}{ Student-Related } & \multicolumn{6}{|c|}{ Non-Student-Related } \\
\hline & \multicolumn{2}{|c|}{ Instruction Total (Logged) } & \multicolumn{2}{|c|}{$\begin{array}{c}\text { Academic Support Total } \\
\text { (Logged) }\end{array}$} & \multicolumn{2}{|c|}{$\begin{array}{l}\text { Student Services Total } \\
\text { (Logged) }\end{array}$} & \multicolumn{2}{|c|}{$\begin{array}{l}\text { Public Service Total } \\
\text { (Logged) }\end{array}$} & \multicolumn{2}{|c|}{$\begin{array}{l}\text { Institutional Support Total } \\
\text { (Logged) }\end{array}$} & \multicolumn{2}{|c|}{$\begin{array}{c}\text { Auxiliary Enterprises Tota } \\
\text { (Logged) }\end{array}$} \\
\hline Promise State2yr & -0.0114 & & $-0.0525^{*}$ & & $-0.0594 * * *$ & & $0.272 * * *$ & & 0.0135 & & $0.267 * * *$ & \\
\hline \multirow[t]{2}{*}{ Promise Single $2 \mathrm{yr}+$ State $2 \mathrm{yr}$} & & -0.0130 & & $-0.0467 *$ & & $-0.0597 * * *$ & & 0.130 & & 0.0234 & & $0.227 * * *$ \\
\hline & & $(0.0108)$ & & $(0.0251)$ & & $(0.0192)$ & & $(0.101)$ & & $(0.0190)$ & & $(0.0717)$ \\
\hline Total Enrollment & $0.145^{* * *}$ & $0.145^{* * *}$ & 0.0756 & 0.0754 & $0.109 * *$ & $0.109^{* *}$ & 0.0371 & 0.0351 & -0.00428 & -0.00407 & 0.0433 & 0.0429 \\
\hline (logged, one year lag) & $(0.0416)$ & $(0.0416)$ & $(0.0545)$ & $(0.0545)$ & $(0.0500)$ & $(0.0500)$ & $(0.156)$ & $(0.156)$ & $(0.0481)$ & $(0.0481)$ & $(0.0847)$ & $(0.0847)$ \\
\hline State and Local Appropriations & 0.00286 & 0.00283 & 0.0226 & 0.0226 & -0.00666 & -0.00672 & 0.106 & 0.104 & $0.164 * * *$ & $0.165 * * *$ & 0.0591 & 0.0588 \\
\hline (logged, one year lag, CPI adjusted) & $(0.0245)$ & $(0.0245)$ & $(0.0214)$ & $(0.0214)$ & $(0.0215)$ & $(0.0215)$ & $(0.0947)$ & $(0.0952)$ & $(0.0547)$ & $(0.0547)$ & $(0.117)$ & $(0.117)$ \\
\hline Total Current Funds Revenues & $0.654 * * *$ & $0.654 * * *$ & $0.610^{* * *}$ & $0.610^{* * *}$ & $0.646 * * *$ & $0.647 * * *$ & $0.689 * * *$ & $0.692 * * *$ & $0.565 * * *$ & $0.564 * * *$ & $0.866^{* * *}$ & $0.867 * * *$ \\
\hline (logged, one year lag, CPI adjusted) & $(0.0892)$ & $(0.0892)$ & $(0.0903)$ & $(0.0903)$ & $(0.0915)$ & $(0.0915)$ & $(0.162)$ & $(0.161)$ & $(0.0905)$ & $(0.0905)$ & $(0.124)$ & $(0.124)$ \\
\hline Constant & $(1.334)$ & $(1.333)$ & $(1.384)$ & $(1.384)$ & $(1.395)$ & $(1.395)$ & $(2.448)$ & $(2.444)$ & $(1.227)$ & $(1.228)$ & $(1.571)$ & $(1.568)$ \\
\hline Institution Fixed Effects? & Yes & Yes & Yes & Yes & Yes & Yes & Yes & Yes & Yes & Yes & Yes & Yes \\
\hline Year Fixed Effects? & Yes & Yes & Yes & Yes & Yes & Yes & Yes & Yes & Yes & Yes & Yes & Yes \\
\hline State-Specific Linear Time Trends? & Yes & Yes & Yes & Yes & Yes & Yes & Yes & Yes & Yes & Yes & Yes & Yes \\
\hline Observations & 11,209 & 11,209 & 11,175 & 11,175 & 11,207 & 11,207 & 7,057 & 7,057 & 11,209 & 11,209 & 9,706 & 9,706 \\
\hline R-squared & 0.605 & 0.605 & 0.253 & 0.252 & 0.392 & 0.392 & 0.066 & 0.064 & 0.408 & 0.408 & 0.105 & 0.104 \\
\hline Number of Institutions & 841 & 841 & 840 & 840 & 841 & 841 & 622 & 622 & 841 & 841 & 787 & 787 \\
\hline
\end{tabular}

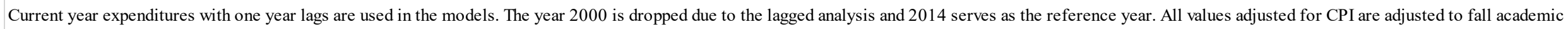
year 2014. Robust standard errors clustered at the institutional level are in parentheses. ${ }^{* * *} \mathrm{p}<0.01,{ }^{* *} \mathrm{p}<0.05,{ }^{*} \mathrm{p}<0.1$ 
Table 3A: Difference-in-Difference Models for Promise Programs at Four-Year Institutions and Current Year Expenditures, Using Single+State Model Specifications, 2000-2014

\begin{tabular}{|c|c|c|c|c|c|c|}
\hline & $(1)$ & (2) & (3) & (4) & $(5)$ & $(6)$ \\
\hline & \multicolumn{3}{|c|}{ Student-Related } & \multicolumn{3}{|c|}{ Non-Student-Related } \\
\hline & $\begin{array}{c}\text { Instruction } \\
\text { Total } \\
\text { (Logged) }\end{array}$ & $\begin{array}{l}\text { Academic } \\
\text { Support } \\
\text { Total } \\
\text { (Logged) }\end{array}$ & $\begin{array}{c}\text { Student } \\
\text { Services } \\
\text { Total } \\
\text { (Logged) }\end{array}$ & $\begin{array}{c}\text { Public } \\
\text { Service Total } \\
\text { (Logged) }\end{array}$ & $\begin{array}{c}\text { Institutional } \\
\text { Support } \\
\text { Total } \\
\text { (Logged) }\end{array}$ & $\begin{array}{c}\text { Auxiliary } \\
\text { Enterprises } \\
\text { Total } \\
\text { (Logged) }\end{array}$ \\
\hline VARIABLES & $\begin{array}{c}\text { Promise } \\
\text { Single4yr + } \\
\text { State4yr }\end{array}$ & $\begin{array}{c}\text { Promise } \\
\text { Single4yr + } \\
\text { State4yr }\end{array}$ & $\begin{array}{c}\text { Promise } \\
\text { Single4yr }+ \\
\text { State4yr }\end{array}$ & $\begin{array}{c}\text { Promise } \\
\text { Single4yr }+ \\
\text { State4yr }\end{array}$ & $\begin{array}{c}\text { Promise } \\
\text { Single4yr }+ \\
\text { State4yr }\end{array}$ & $\begin{array}{c}\text { Promise } \\
\text { Single4yr }+ \\
\text { State4yr }\end{array}$ \\
\hline \multirow[t]{2}{*}{ Promise Single $4 y r+$ State $4 y r$} & 0.00440 & -0.0225 & -0.0218 & 0.0380 & $0.0426 * * *$ & $-0.105 * * *$ \\
\hline & $(0.00825)$ & $(0.0147)$ & $(0.0180)$ & $(0.0875)$ & $(0.0154)$ & $(0.0322)$ \\
\hline Total Enrollment & $0.313 * * *$ & $0.234 * * *$ & $0.322 * * *$ & -0.243 & 0.0534 & $0.451 * * *$ \\
\hline (logged, one year lag) & $(0.0348)$ & $(0.0502)$ & $(0.0487)$ & $(0.171)$ & $(0.0518)$ & $(0.163)$ \\
\hline State and Local Appropriations & $0.0880 * * *$ & $0.105 * * *$ & $0.0394 *$ & -0.000437 & $0.0660 *$ & $-0.102 *$ \\
\hline (logged, one year lag, CPI adjusted) & $(0.0188)$ & $(0.0346)$ & $(0.0236)$ & $(0.0864)$ & $(0.0391)$ & $(0.0534)$ \\
\hline Total Current Funds Revenues & $0.429 * * *$ & $0.409 * * *$ & $0.372 * * *$ & $0.979 * * *$ & $0.622 * * *$ & $0.781 * * *$ \\
\hline (logged, one year lag, CPI adjusted) & $(0.0491)$ & $(0.0586)$ & $(0.0460)$ & $(0.162)$ & $(0.0546)$ & $(0.119)$ \\
\hline \multirow[t]{2}{*}{ Constant } & $5.426 * * *$ & $4.973 * * *$ & $5.701 * * *$ & -0.873 & $3.302 * * *$ & -0.862 \\
\hline & $(0.755)$ & $(0.947)$ & $(0.814)$ & $(3.087)$ & $(0.996)$ & $(2.469)$ \\
\hline Institution Fixed Effects? & Yes & Yes & Yes & Yes & Yes & Yes \\
\hline Year Fixed Effects? & Yes & Yes & Yes & Yes & Yes & Yes \\
\hline State-Specific Linear Time Trends? & Yes & Yes & Yes & Yes & Yes & Yes \\
\hline Observations & 6,978 & 6,992 & 6,992 & 6,600 & 6,992 & 6,936 \\
\hline R-squared & 0.749 & 0.428 & 0.623 & 0.064 & 0.433 & 0.292 \\
\hline Number of Institutions & 540 & 541 & 541 & 507 & 541 & 538 \\
\hline
\end{tabular}

Current year expenditures with one year lags are used in the models. The year 2000 is dropped due to the lagged analysis and 2014 serves as the reference year. All values adjusted for CPI are adjusted to fall academic year 2014. Robust standard errors clustered at the institutional level are in parentheses. $* * * \mathrm{p}<0.01, * * \mathrm{p}<0.05, * \mathrm{p}<0.1$ 
Table 4A: Difference-in-Difference Models for Promise Programs at Two-Year Institutions Share of Expenditures, Using State and Single+State Model Specifications, 2000-2014

\begin{tabular}{|c|c|c|c|c|c|c|c|c|}
\hline & (1) & (2) & (3) & (4) & (5) & (6) & (7) & (8) \\
\hline & \multicolumn{4}{|c|}{ Student-Related } & \multicolumn{4}{|c|}{ Non-Student-Related } \\
\hline & \multicolumn{2}{|c|}{$\begin{array}{l}\text { Education and Related } \\
\text { Expenses }\end{array}$} & \multicolumn{2}{|c|}{$\begin{array}{c}\text { Education and Related } \\
\text { Expenses }\end{array}$} & \multicolumn{2}{|c|}{$\begin{array}{c}\text { Support and Operations and } \\
\text { Maintenance Share of }\end{array}$} & \multicolumn{2}{|c|}{$\begin{array}{l}\text { Public Service-Related } \\
\text { Share of Expenses }\end{array}$} \\
\hline VARIABLES & $\begin{array}{l}\text { Promise } \\
\text { State2yr }\end{array}$ & $\begin{array}{l}\text { Single } 2 \mathrm{yr}+ \\
\text { State2yr }\end{array}$ & $\begin{array}{l}\text { Promise } \\
\text { State2yr }\end{array}$ & $\begin{array}{c}\text { Single } 2 \mathrm{yr}+ \\
\text { State2yr }\end{array}$ & $\begin{array}{l}\text { Promise } \\
\text { State } 2 \mathrm{yr}\end{array}$ & $\begin{array}{c}\text { Single } 2 \mathrm{yr}+ \\
\text { State2yr }\end{array}$ & $\begin{array}{l}\text { Promise } \\
\text { State2yr }\end{array}$ & $\begin{array}{c}\text { Single } 2 \mathrm{yr}+ \\
\text { State2yr }\end{array}$ \\
\hline \multirow[t]{2}{*}{ Promise State2yr } & 0.00173 & & -0.00305 & & 0.00157 & & 0.00155 & \\
\hline & $(0.00435)$ & & $(0.00271)$ & & $(0.00480)$ & & $(0.00241)$ & \\
\hline \multirow[t]{2}{*}{ Promise Single $2 \mathrm{yr}+$ State $2 \mathrm{yr}$} & & $-6.65 e-05$ & & -0.00357 & & 0.00386 & & 0.00120 \\
\hline & & $(0.00386)$ & & $(0.00238)$ & & $(0.00427)$ & & $(0.00231)$ \\
\hline Total Enrollment & $0.0196 * * *$ & $0.0195 * * *$ & 0.000716 & 0.000693 & $-0.0202 * * *$ & $-0.0202 * * *$ & -0.00839 & -0.00839 \\
\hline (logged, one year lag) & $(0.00703)$ & $(0.00703)$ & $(0.00392)$ & $(0.00392)$ & $(0.00668)$ & $(0.00668)$ & $(0.00597)$ & $(0.00597)$ \\
\hline State and Local Appropriations & -0.0102 & -0.0102 & -0.00404 & -0.00405 & $0.0140 * * *$ & $0.0141 * * *$ & 0.00310 & 0.00310 \\
\hline (logged, one year lag, CPI adjusted) & $(0.00625)$ & $(0.00624)$ & $(0.00254)$ & $(0.00254)$ & $(0.00495)$ & $(0.00494)$ & $(0.00450)$ & $(0.00450)$ \\
\hline Total Current Funds Revenues & 0.00365 & 0.00370 & 0.000621 & 0.000653 & -0.00488 & -0.00496 & 0.00572 & 0.00572 \\
\hline (logged, one year lag, CPI adjusted) & $(0.00777)$ & $(0.00777)$ & $(0.00378)$ & $(0.00378)$ & $(0.00697)$ & $(0.00697)$ & $(0.00820)$ & $(0.00820)$ \\
\hline \multirow{2}{*}{ Constant } & $0.222 * *$ & $0.222 * *$ & $0.252 * * *$ & $0.252 * * *$ & $0.539 * * *$ & $0.540 * * *$ & -0.0393 & -0.0393 \\
\hline & $(0.103)$ & $(0.103)$ & $(0.0617)$ & $(0.0617)$ & $(0.106)$ & $(0.106)$ & $(0.109)$ & $(0.109)$ \\
\hline Institution Fixed Effects? & Yes & Yes & Yes & Yes & Yes & Yes & Yes & Yes \\
\hline Year Fixed Effects? & Yes & Yes & Yes & Yes & Yes & Yes & Yes & Yes \\
\hline State-Specific Linear Time Trends? & Yes & Yes & Yes & Yes & Yes & Yes & Yes & Yes \\
\hline Observations & 11,209 & 11,209 & 11,207 & 11,207 & 11,209 & 11,209 & 7,057 & 7,057 \\
\hline R-squared & 0.060 & 0.060 & 0.056 & 0.056 & 0.059 & 0.059 & 0.136 & 0.136 \\
\hline Number of Institutions & 841 & 841 & 841 & 841 & 841 & 841 & 622 & 622 \\
\hline
\end{tabular}

One year lags are used in the models. The year 2000 is dropped due to the lagged analysis and 2014 serves as the reference year. All values adjusted for CPI are adjusted to fall academic year 2014. Robust standard errors clustered at the institutional level are in parentheses. ${ }^{* * *} \mathrm{p}<0.01,{ }^{* *} \mathrm{p}<0.05, * \mathrm{p}<0.1$ 
Table 5A: Difference-in-Difference Models for Promise Programs at Four-Year Institutions Share of Expenditures, Using Single+State Model Specifications, 2000-2014

\begin{tabular}{|c|c|c|c|c|c|}
\hline & $(1)$ & $(2)$ & (3) & $(4)$ & $(5)$ \\
\hline & \multicolumn{2}{|c|}{ Student-Related } & \multicolumn{3}{|c|}{ Non-Student-Related } \\
\hline & $\begin{array}{c}\text { Instruction Share of } \\
\text { Education and } \\
\text { Related Expenses }\end{array}$ & $\begin{array}{l}\text { Student Services } \\
\text { Share of Education } \\
\text { and Related } \\
\text { Expenses }\end{array}$ & $\begin{array}{c}\text { Institutional } \\
\text { Support and } \\
\text { Operations and } \\
\text { Maintenance Share }\end{array}$ & $\begin{array}{l}\text { Public Service- } \\
\text { Related Share of } \\
\text { Expenses }\end{array}$ & $\begin{array}{l}\text { Research-Related } \\
\text { Share of Expenses }\end{array}$ \\
\hline VARIABLES & $\begin{array}{c}\text { Promise Single } 4 y r \\
+ \text { State } 4 y r\end{array}$ & $\begin{array}{c}\text { Promise Single } 4 \mathrm{yr} \\
+ \text { State } 4 \mathrm{yr}\end{array}$ & $\begin{array}{c}\text { Promise Single } 4 \mathrm{yr} \\
+ \text { State } 4 \mathrm{yr}\end{array}$ & $\begin{array}{c}\text { Promise Single } 4 y r \\
+ \text { State } 4 y r\end{array}$ & $\begin{array}{c}\text { Promise Single } 4 \mathrm{yr} \\
+ \text { State } 4 \mathrm{yr}\end{array}$ \\
\hline \multirow[t]{2}{*}{ Promise Single $4 y r+$ State $4 y r$} & 0.00169 & -0.00165 & -0.000148 & -0.000569 & -0.00207 \\
\hline & $(0.00303)$ & $(0.00152)$ & $(0.00286)$ & $(0.00308)$ & $(0.00211)$ \\
\hline Total Enrollment & $0.0269 * *$ & 0.00608 & $-0.0316 * * *$ & $-0.0502 * * *$ & $-0.0237 * *$ \\
\hline (logged, one year lag) & $(0.0108)$ & $(0.00479)$ & $(0.0111)$ & $(0.0104)$ & $(0.00964)$ \\
\hline State and Local Appropriations & 0.000261 & $-0.00409 *$ & 0.00202 & -0.00240 & $-0.00927 * *$ \\
\hline (logged, one year lag, CPI adjusted) & $(0.00389)$ & $(0.00242)$ & $(0.00433)$ & $(0.00462)$ & $(0.00438)$ \\
\hline Total Current Funds Revenues & -0.00441 & -0.00537 & 0.0106 & $0.0360 * * *$ & $0.0347 * * *$ \\
\hline (logged, one year lag, CPI adjusted) & $(0.00952)$ & $(0.00403)$ & $(0.00981)$ & $(0.0102)$ & $(0.0119)$ \\
\hline \multirow[t]{2}{*}{ Constant } & $0.347 * *$ & $0.233 * * *$ & $0.426 * * *$ & -0.0829 & -0.263 \\
\hline & $(0.170)$ & $(0.0766)$ & $(0.152)$ & $(0.138)$ & $(0.169)$ \\
\hline Institution Fixed Effects? & Yes & Yes & Yes & Yes & Yes \\
\hline Year Fixed Effects? & Yes & Yes & Yes & Yes & Yes \\
\hline State-Specific Linear Time Trends? & Yes & Yes & Yes & Yes & Yes \\
\hline Observations & 6,978 & 6,992 & 6,992 & 6,600 & 6,055 \\
\hline R-squared & 0.126 & 0.184 & 0.139 & 0.131 & 0.087 \\
\hline Number of Institutions & 540 & 541 & 541 & 507 & 472 \\
\hline
\end{tabular}

One year lags are used in the models. The year 2000 is dropped due to the lagged analysis and 2014 serves as the reference year. All values adjusted for CPI are adjusted to fall academic year 2014 . Robust standard errors clustered at the institutional level are in parentheses. $* * * \mathrm{p}<0.01, * * \mathrm{p}<0.05, *$ $\mathrm{p}<0.1$ 
Appendix B: List of Institutions that Receive Students with Promise Program Scholarships for Single and Nearest Neighbor Coding, by State and Year

\section{Institution Name}

South Arkansas Community College

Henderson State University

Southern Arkansas University Main Campus

University of Arkansas Community College-Morrilton

Arkansas Northeastern College

College of the Ouachitas

Central Arizona College

College of Alameda

University of California-Berkeley

Long Beach City College

Community College of Denver

Metropolitan State College of Denver

Gateway Community College

Southern Connecticut State University

Illinois Central College

Ivy Tech Community College-Northcentral

Purdue University-Calumet Campus

Garrett College

Lake Michigan College

North Central Michigan College

Oakland Community College

Wayne County Community College District

West Shore Community College

Ferris State University

Lake Superior State University

Michigan State University

Oakland University

Saginaw Valley State University

Wayne State University

Western Michigan University

Delta College

Kellogg Community College

Lansing Community College

Minneapolis Community and Technical College

Saint Paul College - A Community and Technical College

Cumberland County College

Salem Community College

Erie Community College

Orange County Community College

SUNY College of Environmental Science and Forestry

University at Buffalo

Tulsa Community College

Temple University

University of Pittsburgh-Main Campus

Community College of Philadelphia

Columbia State Community College

Jackson State Community College

Northeast State Community College

Pellissippi State Technical Community College

Tennessee State University

Dyersburg State Community College

Seattle Community College-South Campus

Total Number of Institutions by Promise Program Type
Ventura College

Kalamazoo Valley Community College unitid

\begin{tabular}{l|l|l|l|l}
107974 & AR & 2007 & El Dorado Promise
\end{tabular}

107983 AR

107585 AR

107327 AR

107521 AR

104346 AZ

$108667 \mathrm{CA}$

$110635 \mathrm{CA}$

$125028 \mathrm{CA}$

$117645 \mathrm{CA}$

$126942 \mathrm{CO}$

$127565 \mathrm{CO}$

130396 CT

130493 CT

$145682 \mathrm{IL}$

150978 IN

152248 IN

$162609 \mathrm{MD}$

$170541 \mathrm{MI}$

170620 MI

$171395 \mathrm{MI}$

$171535 \mathrm{MI}$

172635 MI

$172671 \mathrm{MI}$

169910 MI

$170639 \mathrm{MI}$

$171100 \mathrm{MI}$

171571 MI

$172051 \mathrm{MI}$

172644 MI

172699 MI

$169521 \mathrm{MI}$

170550 MI

$170657 \mathrm{MI}$

$174136 \mathrm{MN}$

$175041 \mathrm{MN}$

184205 NJ

186469 NJ

$191083 \mathrm{NY}$

$194240 \mathrm{NY}$

$196103 \mathrm{NY}$

$196088 \mathrm{NY}$

207935 OK

216339 PA

$215293 \mathrm{PA}$

215239 PA

219888 TN

220400 TN

$221908 \mathrm{TN}$

$221643 \mathrm{TN}$

221838 TN

220057 TN

236504 WA linchpin State Year Name

\begin{tabular}{l|l|l|l|}
\hline 07071 & AR & 2007 & El Dorado Promise
\end{tabular}
2007 El Dorado Promise

2010 School Counts!

2011 Great River Promise Scholarship

2011 Arkadelphia Promise

2001 Promise of the Future

2003 East Bay Fund

2003 East Bay College Fund

2006 Ventura Promise

2008 Long Beach Promise

2006 Denver Scholarship

2006 Denver Scholarship

2011 New Haven Promise

2011 New Haven Promise

2008 Peoria Promise

2006 College Bound - Hammond

2006 College Bound - Hammond

2006 Garrett County Scholarship Program

2006 Kalamazoo Promise

2006 Kalamazoo Promise

2006 Kalamazoo Promise

2006 Kalamazoo Promise

2006 Detroit College Promise

2006 Kalamazoo Promise

2006 Kalamazoo Promise

2006 Northport Promise

2006 Lansing Promise

2006 Pontiac Promise Zone

2006 Bay Commitment Scholarship

2006 Detroit College Promise

2006 Kalamazoo Promise

2008 Bay Commitment Scholarship

2012 Legacy Scholars

2012 Lansing Promise

2006 Power of YOU

2006 Power of YOU

2002 School Counts!

2006 School Counts!

2008 Say Yes to Education

2008 Say Yes to Education

2008 Say Yes to Education

2009 Say Yes to Education

2007 Tulsa Achieves

2004 CORE Promise

2004 Pittsburgh Promise

2004 CORE Promise

2000 Ayers Foundation

2000 Ayers Foundation

2000 Ayers Foundation

2000 tnAchieves

2000 Ayers Foundation

2006 Dyer County Promise Scholarship

2008 13th Year Promise
Single 4- Nearest 4- Single 2- Nearest 2year year year year

X

\begin{tabular}{|l|l|l}
\hline & $X$ \\
\hline &
\end{tabular}

\begin{tabular}{l|l}
$\mathrm{X}$ & $\mathrm{X}$ \\
$\mathrm{X}$ & $\mathrm{X}$
\end{tabular}

$\mathrm{X} \quad \mathrm{X}$

\begin{tabular}{|l|l|}
\hline & \\
\hline & \\
\hline & $X$ \\
\hline
\end{tabular}

$\mathrm{x}$

$\mathrm{X}$

$\mathrm{X}$
$\mathrm{X}$
$\mathrm{X}$

\begin{tabular}{l|l}
$\mathrm{X}$ & $\mathrm{X}$ \\
$\mathrm{X}$
\end{tabular}
year institutions that receive Promise funds under statewide programs. A complete table with all of these institutions is available from the authors upon request. We coded Promise program start dates as occurring when the first students with Promise funds enrolled in an institution (as opposed to the announcement date of the scholarship). No end dates are listed as all institutions received funds from at least one Promise Program even if another program closed. For instance, the tnAchieves and Ayers Foundation scholarships were folded into the statewide Tennessee Promise program when the latter program was founded. We have coded the data for each institution based on the first Promise program's start date for each year until fall academic year 2014, when the dataset ends. In addition, representative Promise program names are shown, but it is possible for an institution to receive students with Promise funds from multiple different programs (not all possible program names are listed to keep the size of the table manageable). We have coded our data as a dummy variable to indicate if an institution enrolled students from at least one program (we will leave it to future research to investigate if there is a dosage effect on institutions that receive students from multiple Promise programs). The start year refers to the first year that an institution was treated by a Promise program, not the start year of the representative Promise program (in the cases where institutions receive students from multiple Promise programs). For instance, all institutions in MI could receive students with the Kalamazoo promise starting in 2006. In the table, the start year for Wayne State University is listed as 2006 to represent the first year that the institution could receive students with access to Promise funds, not the start year of the listed representative program name, the Detroit Promise (which began in 2009). 


\begin{tabular}{|c|c|c|}
\hline \multicolumn{3}{|l|}{ Appendix C: Delta Cost Project Data Definitions } \\
\hline Dependent Variable Name & $\begin{array}{l}\text { Institutional Expenditure } \\
\text { Type }\end{array}$ & Definition and Calculated Equation \\
\hline Instruction Total (instruction01) & Student-Related & $\begin{array}{l}\text { Instruction - A functional expense category that includes expenses of the colleges, schools, departments, and other instructional divisions of the institution and expenses for departmental research and public service that are not separately } \\
\text { budgeted. Includes general academic instruction, occupational and vocational instruction, community education, preparatory and adult basic education, and regular, special, and extension sessions. Also includes expenses for both credit and non- } \\
\text { credit activities. Excludes expenses for academic administration where the primary function is administration (e.g., academic deans). Information technology expenses related to instructional activities are included if the institution separately } \\
\text { budgets and expenses information technology resources (otherwise these expenses are included in academic support). }\end{array}$ \\
\hline Academic Support Total (acadsupp01) & Student-Related & $\begin{array}{l}\text { Academic support - A functional expense category that includes expenses of activities and services that support the institution's primary missions of instruction, research, and public service. It includes the retention, preservation, and display of } \\
\text { educational materials (for example, libraries, museums, and galleries); organized activities that provide support services to the academic functions of the institution (such as a demonstration school associated with a college of education or } \\
\text { veterinary and dental clinics if their primary purpose is to support the instructional program); media such as audiovisual services; academic administration (including academic deans but not department chairpersons); and formally organized and } \\
\text { separately budgeted academic personnel development and course and curriculum development expenses. Also included are information technology expenses related to academic support activities; if an institution does not separately budget and } \\
\text { expense information technology resources, the costs associated with the three primary programs will be applied to this function and the remainder to institutional support. }\end{array}$ \\
\hline Student Services Total (studserv01) & Student-Related & $\begin{array}{l}\text { Student services - A functional expense category that includes expenses for admissions, registrar activities, and activities whose primary purpose is to contribute to students emotional and physical well-being and to their intellectual, cultural, } \\
\text { and social development outside the context of the formal instructional program. Examples include student activities, cultural events, student newspapers, intramural athletics, student organizations, supplemental instruction outside the normal } \\
\text { administration, and student records. Intercollegiate athletics and student health services may also be included except when operated as self - supporting auxiliary enterprises. Also may include information technology expenses related to studen } \\
\text { service activities if the institution separately budgets and expenses information technology resources(otherwise these expenses are included in institutional support.) }\end{array}$ \\
\hline Public Service Total (pubserv01) & Non-Student-Related & $\begin{array}{l}\text { Public service - A functional expense category that includes expenses for activities established primarily to provide noninstructional services beneficial to individuals and groups external to the institution. Examples are conferences, institutes, } \\
\text { general advisory service, reference bureaus, and similar services provided to particular sectors of the community. This function includes expenses for community services, cooperative extension services, and public broadcasting services. Also } \\
\text { includes information technology expenses related to the public service activities if the institution separately budgets and expenses information technology resources (otherwise these expenses are included in academic support). }\end{array}$ \\
\hline Auxiliary Enterprises Total (auxiliary01) & Non-Student-Related & $\begin{array}{l}\text { Auxiliary enterprises - total expenses is the sum of all operating expenses associated with essentially self-supporting operations of the institution that exist to furnish a service to students, faculty, or staff, and that charge a fee that is directly } \\
\text { related to, although not necessarily equal to, the cost of the service. Examples are residence halls, food services, student health services, intercollegiate athletics (only if essentially self-supporting), college unions, college stores, faculty and } \\
\text { staff parking, and faculty housing. }\end{array}$ \\
\hline $\begin{array}{l}\text { Instruction Share of Education and Related Expenses } \\
\text { (instruction_share) }\end{array}$ & Student-Related Share & The share of education and related spending on instruction. (instruction01/eandr) \\
\hline $\begin{array}{l}\text { Student Services Share of Education and Related Expenses } \\
\text { (studserv_ share) }\end{array}$ & Student-Related Share & The share of education and related spending on student services. (studserv01/eandr) \\
\hline $\begin{array}{l}\text { Academic and Institutional Support and Operations and } \\
\text { Maintenance Share of Education and Related Expenses } \\
\text { (admin_hare) }\end{array}$ & Non-Student-Related Share & $\begin{array}{l}\text { The share of education and related spending on other education and related costs (the portion of spending on academic support, institutional support, and operations and maintenance ascribed to the education function). } \\
\text { (other_ed__elated_costleandr) }\end{array}$ \\
\hline Public Service-Related Share of Expenses (pubserv_share) & Non-Student-Related Share & $\begin{array}{l}\text { The public service share of spending on research, instruction, student services, and public services. This variable is used in the calculation of public service and related expenses. } \\
\text { (pubserv01/sum(instruction01,studserv01, research01,pubserv01))) }\end{array}$ \\
\hline Research-Related Share of Expenses (research_share) & Non-Student-Related Share & The research share of spending on research, instruction, student services, and public services. This variable is used in the calculation of research and related expenses. ((research01/sum(instruction01, studserv01, research01,pubserv01))) \\
\hline
\end{tabular}

